\title{
Activated Carbon, Carbon Nanotubes and Graphene: Materials and Composites for Advanced Water Purification
}

\author{
Martin J. Sweetman ${ }^{1,2}$, Steve May ${ }^{3}$, Nick Mebberson ${ }^{3}$, Phillip Pendleton ${ }^{4}$, Krasimir Vasilev ${ }^{5}$, \\ Sally E. Plush 2,6,* and John D. Hayball 1,7,* \\ 1 Experimental Therapeutics Laboratory, Sanson Institute, University of South Australia, Adelaide, SA 5000, \\ Australia; martin.sweetman@unisa.edu.au \\ 2 School of Pharmacy and Medical Sciences, University of South Australia, Adelaide, SA 5000, Australia \\ 3 Puratap Pty. Ltd., Stepney, SA 5069, Australia; steve.puratap@gmail.com (S.M.); \\ nick.puratap@gmail.com (N.M.) \\ 4 School of Chemical Engineering, University of Adelaide, Adelaide, SA 5000, Australia; \\ Phillip.pendleton@adelaide.edu.au \\ 5 School of Engineering, University of South Australia, Mawson Lakes, SA 5095, Australia; \\ krasimir.vasilev@unisa.edu.au \\ 6 Future Industries Institute, University of South Australia, Mawson Lakes, SA 5095, Australia \\ 7 Robinson Research Institute, Discipline of Obstetrics and Gynaecology, School of Medicine, \\ University of Adelaide, SA 5005, Australia \\ * Correspondence: sally.plush@unisa.edu.au (S.E.P.); john.hayball@unisa.edu.au (J.D.H.); \\ Tel.: +61-8-8302-2586 (S.E.P.); +61-8-8302-1202 (J.D.H.)
}

Academic Editor: Giuseppe Cirillo

Received: 3 May 2017; Accepted: 28 May 2017; Published: 2 June 2017

\begin{abstract}
To ensure the availability of clean water for humans into the future, efficient and cost-effective water purification technology will be required. The rapidly decreasing quality of water and the growing global demand for this scarce resource has driven the pursuit of high-performance purification materials, particularly for application as point-of-use devices. This review will introduce the main types of natural and artificial contaminants that are present in water and the challenges associated with their effective removal. The efficiency and performance of recently developed materials for water purification, with a focus on activated carbon, carbon nanotubes and graphene will be discussed. The recent advances in water purification using these materials is reviewed and their applicability as point-of-use water purification systems discussed.
\end{abstract}

Keywords: water purification; activated carbon; carbon nanotubes; graphene; water contamination; point-of-use

\section{Introduction}

With an increasing global usage and a growing demand for high purity, water is fast becoming one of the most important resources used by humans. Essential for the survival of life on earth, the effective management, distribution, storage, recycling and purification of water are critical to ensure the sustainable use of this resource into the future. Water is necessary for many human activities including agriculture, industrial processes, recreation and most importantly consumption.

As all water used is collected from natural sources, a proper treatment and purification process is required. Conventionally this treatment process has been applied to remove natural organic material, sediments and harmful pathogens from water prior to distribution. Recently however, the integrity of the treatment and purification process is being stressed due to widespread, human-induced 
contamination of source water. Contaminant materials from industrial processes, agricultural practices and synthetic chemicals such as pharmaceuticals and cosmetics often find their way into water systems, adding to the naturally occurring impurities $[1,2]$.

Naturally occurring contaminants in water can be either compounds derived from the breakdown of organic matter that only pose low health impact to humans, and bacteria and viruses that can have significant health implications [3,4]. Artificial contaminants, derived from human practices, may include toxic organic compounds (dyes, pesticides, pharmaceuticals), heavy metals, and by-products produced by the water treatment process itself [5]. Due to the varied chemical and physical properties of the natural and artificial contaminant species, it remains a challenge to find methods that can effectively remove all hazardous materials from water in a single process.

Water treatment processes are constantly being improved, with the aim to remove as high proportion of the contaminant species as possible. However, studies indicate that many potentially harmful compounds are still present, post treatment [6,7]. For this reason, there has been an increasing uptake of point-of-use (POU) water purification devices by individuals to deliver the cleanest possible water. In most cases POU water purification is used by individuals for home use, however larger scale water purification systems have also been integrated in industrial water treatment settings $[8,9]$. There is also significant interest in the use of water purification devices to deliver clean water in remote and isolated communities, where the supply of treated and purified water is limited or even non-existent. In these situations, the dual action of toxin removal and microorganism neutralization is requisite.

The most promising materials for delivering pure water are those that incorporate nanoscale features and tailorable chemical properties. Activated carbon (AC) is currently the most widely used example of this type of purification substrate and is often applied for POU devices, with many commercial systems utilizing this material for home applications. Activated carbon is a highly porous material that acts to remove contaminant species from water based primarily on surface adsorption [10]. It has been proven to be effective in removing high amounts of organic species from water and is currently the most cost-effective material for individual POU devices [11]. In recent times however there have been significant advances towards improving water purification, by applying modifications to the existing AC substrate [12]. In particular, the use of chemical treatments to improve the capture efficiency for organic and inorganic materials and through biological modifications to AC [12].

Advanced nanomaterials for high-performance water purification are also under development, with carbon nanotubes (CNTs), graphene and composite materials of each showing promising results [13]. These nanomaterials are based on the graphite-like carbon framework and commonly utilize an adsorption strategy for removing contaminant species. These materials have also shown promise as size exclusion membrane filters that allow the flow of water while blocking the flow of contaminants [14]. Certain chemical modifications or composites of the mentioned nanomaterials have also been shown as effective for the neutralization of harmful water borne pathogens [15]. The current cost of fabricating these composite graphene or CNT water purification materials make them as yet impractical for commercial sale, however many see these materials as the platform for next generation water purification, with high performance and versatility capabilities [11]. As the cost of manufacture is lowered, it is likely that these materials will become more widespread in POU water purification systems.

This review will introduce the current state of water health, identifying the major contaminant species of concern to humans and the challenges associated with the effective removal of these species. The performance of recently developed AC, CNTs and graphene materials and their composites for water purification will be explored. The properties and adsorption performance of these materials will be reviewed, including recent efforts directed at improving the performance through chemical and biological treatments. An assessment of these materials applicability for POU water purification will also be discussed. 


\section{Classifications of Water Contaminant Species}

The health of the world's waterways and natural bodies of fresh water have been in decline for many decades. Rapidly expanding industrial practices, agricultural impacts and the effects from a growing global human population have all led to an increase in the amount of contaminant species ending up in the water system. Contamination in water is comprised of both natural and artificial components, with each species affecting human health to varying degrees. Table 1 provides an overview of the major contaminant classes and example species in each, including their current removal strategies and associated removal difficulties.

\subsection{Naturally Occurring Water Contaminants}

A significant proportion of contamination and impurities in water originates from naturally occurring sources [16]. Allochthonous contamination is derived from the breakdown of terrestrial plant and animal matter, which is subsequently transported into the waterways [17]. Autochthonous contamination originates from within each waterway, arising from the natural actions of the microorganisms and breakdown of aquatic vegetation [18]. Along with the myriad of individual chemical compounds that constitute the natural organic matter, the microorganisms including bacteria and viruses are also classified as natural water contaminants. While for the most part, the organic compounds are considered to be relatively benign to human health, certain microorganisms can have significant and widespread health effects [19].

\subsection{Artificially Derived Water Contaminant Species}

Over several decades, an increase in the concentration and variation of artificial chemical species has percolated into global waterways. The rise in industry, agriculture and the disposable nature of modern society has contributed a vast number of synthetic organic and inorganic contaminants to the water system. Industrial contaminant species include heavy metals and synthetic organic compounds such as dyes and plasticizers. Due to the considerable diversity of industrial derived contaminants, covering both organic and inorganic species, these are perhaps the most difficult to effectively remove from water [20,21]. Agriculturally derived contaminant species including pesticides and fertilizers are also commonly found in waterways, contributing to the release of phosphorous and nitrogen, with the potential to cause a rise in harmful microorganisms [22,23]. Another growing source of artificial water contamination is from pharmaceutical and cosmetic products [24]. While the release of hormonal compounds and specific therapeutics are alarming, it is the release of antibiotics that is of significant concern due to the possibility for the rise of resistant bacteria [25].

Of importance in the context of POU water purification are the contaminant species that result from the practice of sterilizing water during the treatment process. Disinfectant by-products (DBPs) are a class of species comprising small organic compounds that result from the reaction of disinfectant species (chlorine, chloramine) with the dissolved organic matter (DOM). The two main described DBPs that can form during this process are trihalomethanes (THMs) and haloacetic acids (HAAs) [26]. These species are small halogenated organic compounds that have been linked to adverse health effects in humans and are often a key target for POU water purification devices [27]. 
Table 1. Overview of current water contaminant species, removal methods and associated challenges.

\begin{tabular}{|c|c|c|c|c|}
\hline Contaminant Class & Example Species & Removal Methods & Removal Challenges & References \\
\hline Natural organic matter & $\begin{array}{l}\text { Humic acids } \\
\text { Fulvic acids } \\
\text { Proteins }\end{array}$ & $\begin{array}{l}\text { Flocculation/sedimentation } \\
\text { Filtration } \\
\text { Adsorption }\end{array}$ & $\begin{array}{l}\text { Wide range of functionalities, sizes } \\
\text { Different mixture of compounds for each water source, with } \\
\text { seasonal variations } \\
\text { Adsorption affected by environmental factors and other } \\
\text { contaminant species ( } \mathrm{pH} \text {, temperature) }\end{array}$ & [28-30] \\
\hline Microorganism & $\begin{array}{l}\text { Bacteria } \\
\text { Viruses } \\
\text { Protozoa }\end{array}$ & $\begin{array}{l}\text { Chlorine disinfection } \\
\text { Size exclusion filtration } \\
\text { Neutralization by nanomaterials }\end{array}$ & $\begin{array}{l}\text { Chlorine disinfection leads to DBPs } \\
\text { Neutralization must meet regulation requirements } \\
\text { Size exclusion does not capture all microorganisms } \\
\text { Potential release of nanoparticles/nanomaterials into ecosystem }\end{array}$ & [31-33] \\
\hline Disinfectant by-products & $\begin{array}{l}\text { Trihalomethanes } \\
\text { Haloacetic acids } \\
\text { Halonitromethanes } \\
\text { Haloamides } \\
\text { Nitrosamines }\end{array}$ & Adsorption & $\begin{array}{l}\text { Too small for ultrafiltration } \\
\text { Regulatory guidelines for maximum concentrations apply }\end{array}$ & {$[26,27,34,35$} \\
\hline Heavy metals & $\begin{array}{l}\text { Arsenic } \\
\text { Mercury } \\
\text { Lead } \\
\text { Cadmium } \\
\text { Chromium }\end{array}$ & $\begin{array}{l}\text { Ion-exchange } \\
\text { Adsorption } \\
\text { Filtration } \\
\text { Reverse osmosis } \\
\text { Flocculation/sedimentation }\end{array}$ & $\begin{array}{l}\text { Both cation and anions present } \\
\text { Range of adsorption affinities } \\
\text { Adsorptions effected by other contaminant species }\end{array}$ & {$[36,37]$} \\
\hline Synthetic organics & $\begin{array}{l}\text { Dyes } \\
\text { Plasticizers } \\
\text { Solvents } \\
\text { Perfluorinated compounds }\end{array}$ & $\begin{array}{l}\text { Adsorption } \\
\text { Filtration } \\
\text { Degradation }\end{array}$ & $\begin{array}{l}\text { Wide range of chemistries and molecular weights } \\
\text { Properties can be affected by environmental factors ( } \mathrm{pH} \text {, } \\
\text { temperature, ionic concentration) }\end{array}$ & [38] \\
\hline Pharmaceuticals & $\begin{array}{l}\text { Hormones } \\
\text { Steroids } \\
\text { Analgesics } \\
\text { Antibiotics } \\
\text { Cosmetics }\end{array}$ & $\begin{array}{l}\text { Adsorption } \\
\text { Filtration } \\
\text { Degradation }\end{array}$ & $\begin{array}{l}\text { Both hydrophilic and hydrophobic compounds are present } \\
\text { Some species have low affinity to adsorbents }\end{array}$ & {$[39,40]$} \\
\hline Agriculturally derived & $\begin{array}{l}\text { Pesticides } \\
\text { Fertiliser } \\
\text { Animal waste }\end{array}$ & $\begin{array}{l}\text { Adsorption } \\
\text { Filtration } \\
\text { Flocculation/sedimentation } \\
\text { Reverse osmosis }\end{array}$ & Wide range of chemistries and molecular weights & {$[41,42]$} \\
\hline
\end{tabular}




\section{Activated Carbon for Water Purification}

Activated carbon is currently widely used as an adsorbent material in both water treatment plants and for POU water purification. Activated carbon is characterized as a carbonaceous material with a highly porous internal structure, which is usually derived from the pyrolysis and chemical treatment of sources including wood, coal, nutshells, bamboo and other organic materials [43]. The activation process, usually performed at high temperature by chemical or steam treatment, generates an extensive porous network within the carbonaceous material [44]. The adsorptive properties of AC towards organic contaminants have been widely recognized and studied for many years, with this material well suited for removing contaminant species from water. The majority of POU water purification devices that are currently in use are comprised of $\mathrm{AC}$, as this material has the appropriate balance between performance and cost. Many AC POU devices operate under mains water pressure and flow water through a formed carbon block, where the density of packed AC particles results in maximum internal pore sizes that range from $0.5-10 \mu \mathrm{m}$. Other AC POU purification devices operate by a gravity mechanism, where water passes over larger AC particles to enable contaminant adsorption.

\subsection{Properties of Activated Carbon Relevant to Water Purification}

In general, $\mathrm{AC}$ is classified based on the average particle size, as either powdered or granular AC (PAC of GAC respectively). Powdered activated carbon constitutes particles $<80 \mu \mathrm{m}$, with an average size between 10 and $50 \mu \mathrm{m}$, while GAC are larger particles of between 0.2 and $5 \mu \mathrm{m}[43,45]$. Other forms of AC include extruded AC and block AC, which are either PAC or GAC that have been compressed and held together with a thermoplastic binding agent.

Activated carbon has a highly porous internal structure with a heterogeneous range of pore diameters. Macro $(>50 \mathrm{~nm})$, meso $(2-50 \mathrm{~nm})$ and micro $(<2 \mathrm{~nm})$ pores are all present in the highly branched internal structure of AC [46]. The main effect of this high porosity structure is to impart a high surface area to $\mathrm{AC}$, up to $2500 \mathrm{~m}^{2} / \mathrm{g}$ [47]. Consequently, this results in a large number of binding sites for adsorbate species to interact with. The exact internal pore composition of $\mathrm{AC}$ is determined by the source material, activation process and any further chemical modifications.

The carbonaceous chemical structure can be loosely described as graphite like, however impurities or specific chemicals present during the activation process can lead to the incorporation of surface functional groups such as phenols, carboxylic acids and pyridines [48]. The typical elemental composition of $\mathrm{AC}$ is around $80 \%$ carbon, with other elements including oxygen and nitrogen accounting for the remaining material $[49,50]$.

Both the physical and chemical properties of AC will affect the adsorption capacities to different organic and inorganic species $[12,51]$. The adsorption mechanism and capacity of native and modified AC will be discussed in the following sections.

\subsection{Adsorption Mechanism of Activated Carbon}

Due to the graphite like carbonaceous structure of AC, it is ideally suited to adsorbing organic compounds, especially species containing aromatic functionality [49,50]. Activated carbon also has a high adsorption capacity for small organic species such as DBPs and some pharmaceutical compounds [52]. Adsorption is generally through $\pi-\pi$ interactions between the adsorbate and the AC surface, but will also occur through hydrogen bonding and Van der Waals interactions [53,54]. This material also has the capacity for cation/anion- $\pi$ interactions with metal species, but this process is generally considered to be poor, especially for native AC. The adsorption of species to AC will be directly influenced by environmental factors including $\mathrm{pH}$, ionic concentration, temperature and the concentration of other contaminant species, which can have both positive and negative effects depending on the adsorbate in question [30,55-57]. The physical size of compounds interacting with $\mathrm{AC}$ will also have an effect on the adsorption capacity and efficiency, with larger compounds likely to cause pore blockage and limit the diffusion of subsequent smaller species [58,59]. 


\subsection{Chemical Modifications of Activated Carbon for Improved Contaminant Adsorption}

As AC is such a widely used and accepted material for water purification, considerable research has been carried out into chemically modifying the surface in order to impart a higher adsorption or wider ranging capacity to the material. Chemical modification of $\mathrm{AC}$ can increase the selectivity of the material to certain species, usually through the introduction of acidic or basic surface functionality. This has primarily been achieved through acid or base chemical treatment procedures, which impart a more negative or positive surface charge respectively. This has implications for the adsorption of cationic and anionic compounds and also for charged organic species such as dyes [60].

For acid modification of $\mathrm{AC}$, treatment with $\mathrm{HNO}_{3}, \mathrm{H}_{2} \mathrm{SO}_{4}$ and $\mathrm{HCl}$ is commonly used, under different temperature and reaction conditions. In this case, the net effect is to increase the abundance of acidic or oxidative functional groups on the AC surface, such as carboxylic acids, alcohols and lactones [61]. When operated in aqueous media with a $\mathrm{pH}>\mathrm{pK}_{\mathrm{a}}$ of the acidic functional groups, the surface carries a negative charge that improves the adsorption of positively charged species [62].

Base treatment of $\mathrm{AC}$ with $\mathrm{NaOH}, \mathrm{NH}_{3}$ and $\mathrm{KOH}$ results in an increase in basic functionality on the AC surface through generation of amides and aromatic amines [12,63]. High temperature treatment of the AC, where oxygen species are removed from the surface can also be employed to impart a higher degree of basicity to AC [64]. Such surface chemistry will improve the adsorption of negatively charged compounds.

The main disadvantage of the acid or base treatment of $\mathrm{AC}$ is that depending on the chosen treatment method, the AC becomes more selective towards certain species, but loses adsorption capacity to others. This may be beneficial in the case where known quantities of a specific contaminant are present, however in the context of POU water purification highly specific selectivity would be undesirable. The development of $\mathrm{AC}$ for application in POU water purification devices requires the appropriate balance of selectivity, with a high adsorption capacity for a range of contaminant species.

One of the other chemical modifications to $A C$ that is gaining interest in the impregnation of metal or metal oxide nanoparticles into the porous structure [65]. Metal impregnated AC is commonly prepared by the reduction of metal salt solutions, or by direct adsorption of pre-prepared nanoparticles [66,67]. These composite materials have shown high adsorption affinities for contaminant species including heavy metals, halides and DOM. The removal efficiency for bromide and iodide for native and silver impregnated AC was compared, with results showing a far superior removal of bromide by the silver impregnated material ( $95 \%$ as compared to $26 \%$ for native AC) [68]. This material also showed an improved efficiency for the removal of total dissolved organic carbon when used in conjunction with an enhanced coagulation process ( $77 \%$ as compared to $67 \%$ ).

For heavy metal adsorption, native AC adsorption capacities for $\operatorname{Ar}(\mathrm{III}), \operatorname{Ar}(\mathrm{V}), \mathrm{Hg}$ (II) and $\mathrm{Pb}$ (II) were found to be $0.73,0.09,2.61$ and $3.06 \mathrm{mg} / \mathrm{g}$ respectively, while adsorptions on iron impregnated AC were $4.67,4.50,4.57$ and $4.35 \mathrm{mg} / \mathrm{g}$ respectively [65]. Activated carbons impregnated with silver nanoparticles have also been specifically investigated for their antibacterial effect and are promising materials for the treatment of contaminated water in the absence of conventional water treatment processes $[69,70]$. While promising, there are ongoing concerns about possible leaching of metal nanoparticles from these composites. It is for this reason that metal impregnated AC will not be used as a material in POU water purification devices until these issues have been definitely resolved.

The use of microwave heating for either the preparation or modification of $\mathrm{AC}$ has also been used as a viable method to prepare AC with improved adsorption capacity to certain species [71]. While not a direct chemical modification, microwave heating can result in physical and chemical alterations to AC, when compared to the conventional activation process. This can include variations in the internal surface area, altered pore size distributions and changes to the native surface chemistry [72,73]. Microwave treatment as a means to prepare AC may prove to be beneficial in terms of lower power consumption and preparation time.

The chemical and physical effects to AC, along with the targeted contaminant species and adsorption capacities for a selection of recent studies using the above mentioned chemical modification 
methods are summarized in Table 2. For each modification, generally only one contaminant species was selected to assess the adsorption improvement of the AC. It would be beneficial to specifically understand $\mathrm{AC}^{\prime}$ 's adsorption capacity for certain species in the presence of multiple adsorbates. Relatively few studies have considered the effect of competitive adsorption or any positive or negative effects that can arise from complex mixtures [55,59]. In the context of POU water purification, a study of this nature would be highly relevant, as a range of contaminant species at varying concentrations are likely to be present. Due to the varying composition of water contamination at different locations, the construction of tailored AC POU purification devices may prove the most effective means to deliver clean water. Tools, including chemo- and bio-sensors, for the rapid assessment of water contaminant species, may be used to direct the types of modified ACs (as discussed in this review) for the fabrication of a specific, high-performance POU water purification device. Of the carbon materials reviewed here, AC has been investigated most broadly for the removal of many different water contaminant species. The next steps for AC research in water purification should be investigations into competitive adsorption of contaminant species and a move towards location specific POU devices. In turn, investigations of this nature will lead onto determining the saturation points for certain contaminant mixtures adsorbing onto AC. The time or filtrate volume to reach saturation point will be location/water source specific, however a deeper understanding of the mechanisms and contaminant levels required to reach saturation will be beneficial in the pursuit of tailored AC POU devices. 
Table 2. Chemical modifications of AC, target contaminants and adsorption capacities for specific species.

\begin{tabular}{|c|c|c|c|c|c|c|c|}
\hline \multirow{2}{*}{$\begin{array}{l}\text { Modification } \\
\text { Method }\end{array}$} & \multirow{2}{*}{ Modification Conditions } & \multirow{2}{*}{$\begin{array}{l}\text { Carbon Source } \\
\text { Material }\end{array}$} & \multirow{2}{*}{ Effect on Native Activated Carbon } & \multirow{2}{*}{ Target Species } & \multicolumn{2}{|c|}{ Adsorption Capacity (mg/g) } & \multirow{2}{*}{ Ref. } \\
\hline & & & & & Native AC & Modified AC & \\
\hline \multirow[t]{8}{*}{ Acid treatment } & $\mathrm{HNO}_{3}+\mathrm{MW}\left(130{ }^{\circ} \mathrm{C}, 800 \mathrm{~W}\right)$ & Rice husk & $\begin{array}{l}\text { Increase oxide content } \\
\text { Reduction in total surface area, small increase in } \\
\text { micropore area }\end{array}$ & $\mathrm{Pb}(\mathrm{II})$ & 66.23 & 95.24 & [74] \\
\hline & $\mathrm{HNO}_{3}\left(120{ }^{\circ} \mathrm{C}, 48 \mathrm{~h}\right)$ & Not specified & $\begin{array}{l}\text { Increased surface area } \\
\text { Increased carboxylic acid groups }\end{array}$ & $\mathrm{Cr}(\mathrm{VI})$ & 3.46 & 18.519 & [75] \\
\hline & $\begin{array}{l}\text { (i) } \mathrm{HNO}_{3}\left(60^{\circ} \mathrm{C}, 3 \mathrm{~h}+300^{\circ} \mathrm{C}, 3 \mathrm{~h}\right) \\
\text { (ii) } \mathrm{H}_{2} \mathrm{SO}_{4}\left(60^{\circ} \mathrm{C}, 3 \mathrm{~h}+300^{\circ} \mathrm{C}, 3 \mathrm{~h}\right)\end{array}$ & $\begin{array}{l}\text { Aerobic granular } \\
\text { sludge }\end{array}$ & $\begin{array}{l}\text { Increased surface acid groups } \\
\text { Decrease in surface area (reduction in micropores) }\end{array}$ & Malachite Green & 269.54 & $\begin{array}{l}\text { (i) } 303.03 \\
\text { (ii) } 284.90 \\
\end{array}$ & [76] \\
\hline & $\mathrm{HNO}_{3}\left(120^{\circ} \mathrm{C}, 48 \mathrm{~h}\right)$ & Not specified & $\begin{array}{l}\text { Increased surface area } \\
\text { Increased carboxylic acid groups }\end{array}$ & $\mathrm{Cd}(\mathrm{II})$ & $\mathrm{N} / \mathrm{A}$ & 1.98 & [77] \\
\hline & $\mathrm{H}_{3} \mathrm{PO}_{4}\left(110{ }^{\circ} \mathrm{C}, 9 \mathrm{~h}\right)+380{ }^{\circ} \mathrm{C}$ & Olive stone & $\begin{array}{l}\text { Narrow microporosity range } \\
\text { High number of acidic surface groups }\end{array}$ & Amoxicillin & $\mathrm{N} / \mathrm{A}$ & 57.0 & [78] \\
\hline & $\mathrm{H}_{2} \mathrm{SO}_{4}+\mathrm{MW}\left(450^{\circ} \mathrm{C}, 700 \mathrm{~W}, 20 \mathrm{~min}\right)$ & Rice straw & $\begin{array}{l}\text { Increased AC surface roughness } \\
\text { Increased overall porosity }\end{array}$ & MB & $\mathrm{N} / \mathrm{A}$ & 62.5 & [79] \\
\hline & $\begin{array}{l}\mathrm{H}_{2} \mathrm{SO}_{4} / \mathrm{H}_{3} \mathrm{PO}_{4}+\mathrm{MW} \\
(24 \mathrm{~h} \mathrm{RT}, 300 \mathrm{~W}, 3 \mathrm{~min})\end{array}$ & Cherry stone & $\begin{array}{l}\text { Increase in micropore volume from } 767 \mathrm{~m}^{2} / \mathrm{g} \text { to } \\
1998 \mathrm{~m}^{2} / \mathrm{g} \\
\text { Significantly shorter activation time }\end{array}$ & Disperse yellow 211 & $\mathrm{~N} / \mathrm{A}$ & 283.3 & [80] \\
\hline & $\begin{array}{l}\text { Lime, } \mathrm{ZnCl}_{2}, \mathrm{FeCl}_{3},+\mathrm{MW} \\
(320 \mathrm{~s}, 120 \mathrm{~W})\end{array}$ & $\begin{array}{l}\text { Sapelli wood } \\
\text { sawdust }\end{array}$ & $\begin{array}{l}\text { High degree of microporosity } \\
\text { Surface area of } 914.08 \mathrm{~m}^{2} / \mathrm{g}\end{array}$ & o-cresol & $\mathrm{N} / \mathrm{A}$ & 239.2 & [81] \\
\hline \multirow[t]{7}{*}{ Base treatment } & $\begin{array}{l}\mathrm{NH}_{3}\left(35^{\circ} \mathrm{C}, 12 \mathrm{~h}\right) \\
\mathrm{MW}(500 \mathrm{~W}, 8 \mathrm{~min})\end{array}$ & Coal & $\begin{array}{l}\text { Increased basicity (higher PZC) } \\
\text { Increased surface area and pore volume }\end{array}$ & $\begin{array}{l}\text { Polyaromatic } \\
\text { hydrocarbons (pyrene) }\end{array}$ & 142.86 & 250.00 & [82] \\
\hline & $\begin{array}{l}1000{ }^{\circ} \mathrm{C} \text { under } \mathrm{Ar} \\
700^{\circ} \mathrm{C} \text { under } \mathrm{NH}_{3}\end{array}$ & $\begin{array}{l}\text { (i) Coal } \\
\text { (ii) Coconut shell } \\
\text { (iii) Wood } \\
\text { (iv) Phenolic AC } \\
\text { fiber }\end{array}$ & $\begin{array}{l}\text { Reduction of oxygen content }(70 \%) \\
\text { Increased PZC ( } 7) \\
\text { Increase in surface basicity through nitrogen } \\
\text { functionality incorporation } \\
\text { Variations observed for different source AC }\end{array}$ & $\begin{array}{l}\text { Perfluorooctane sulfonic } \\
\text { acid }\end{array}$ & $\begin{array}{l}\text { (i) } 1.11 \\
\text { (ii) } 1.72 \\
\text { (iii) } 2.70 \\
\text { (iv) } 3.54\end{array}$ & $\begin{array}{l}\text { (i) } 2.16 \\
\text { (ii) } 17.0 \\
\text { (iii) } 85.2 \\
\text { (iv) } 85.6\end{array}$ & [64] \\
\hline & $\begin{array}{l}\mathrm{NaOH}(2 \mathrm{~h}) \\
700^{\circ} \mathrm{C}(90 \mathrm{~min})\end{array}$ & $\begin{array}{l}\text { Macadamia nut } \\
\text { shells }\end{array}$ & $\begin{array}{l}\text { High surface area AC } \\
\text { Large percentage of micropores } \\
\text { PZC }>8\end{array}$ & Tetracycline & $58.82 *$ & 455.8 & [83] \\
\hline & $\begin{array}{l}\text { MW }(8 \mathrm{~min}) \\
\text { (i) } 300 \mathrm{~W} \\
\text { (ii) } 500 \mathrm{~W} \\
\text { (iii) } 700 \mathrm{~W} \\
\end{array}$ & Coal & $\begin{array}{l}\text { Removal of oxide groups (increased basicity) } \\
\text { Increased surface area and pore volume }\end{array}$ & Naphthalene & 111.79 & $\begin{array}{l}\text { (i) } 125.22 \\
\text { (ii) } 131.20 \\
\text { (iii) } 129.05\end{array}$ & [73] \\
\hline & $\begin{array}{l}\text { (i) } \mathrm{KOH} \\
\text { (ii) } \mathrm{K}_{2} \mathrm{CO}_{3}\end{array}$ & Sucrose & $\begin{array}{l}\text { (i) } \mathrm{KOH} \text { treatment leads to very high surface area } \\
\text { ( } 2400 \mathrm{~m}^{2} / \mathrm{g} \text { ) and wide micropore distribution } \\
\text { (ii) } \mathrm{K}_{2} \mathrm{CO}_{3} \text { treatment results in } 1400 \mathrm{~m}^{2} / \mathrm{g} \text { surface area } \\
\text { and ultramicropore sizes }\end{array}$ & $\begin{array}{l}\text { Ibuprofen, paracetamol, } \\
\text { clofibric acid, caffeine, } \\
\text { iopamidol }\end{array}$ & $\begin{array}{l}255 \text { (Paracetamol) } \\
147 \text { (Iopamidol) }\end{array}$ & $\begin{array}{l}514 \text { (Paracetamol) } \\
1050 \text { (Iopamidol) }\end{array}$ & [84] \\
\hline & Vapor and solution-based amination & Petroleum coke & $\begin{array}{l}\text { Decrease in specific surface area from both treatments } \\
\text { Increase in PZC }\end{array}$ & 2-Naphthoic acid & 189 & $\begin{array}{l}214 \text { (vapour) } \\
298 \text { (solution) }\end{array}$ & [85] \\
\hline & $\mathrm{KOH}+\mathrm{MW}(12 \mathrm{~min}, 600 \mathrm{~W})$ & $\begin{array}{l}\text { Rambutan } \\
\text { peel }\end{array}$ & $\begin{array}{l}\text { High surface area AC } \\
\text { Short preparation time }\end{array}$ & Acid yellow 17 & 133.3 & 215.05 & [86] \\
\hline
\end{tabular}


Table 2. Cont

\begin{tabular}{|c|c|c|c|c|c|c|c|}
\hline \multirow{2}{*}{$\begin{array}{l}\text { Modification } \\
\text { Method }\end{array}$} & \multirow{2}{*}{ Modification Conditions } & \multirow{2}{*}{$\begin{array}{l}\text { Carbon Source } \\
\text { Material }\end{array}$} & \multirow{2}{*}{ Effect on Native Activated Carbon } & \multirow{2}{*}{ Target Species } & \multicolumn{2}{|c|}{ Adsorption Capacity (mg/g) } & \multirow{2}{*}{ Ref. } \\
\hline & & & & & Native AC & Modified AC & \\
\hline \multirow[t]{8}{*}{ Impregnation } & Reduction of $\mathrm{Cu}, \mathrm{Pb}, \mathrm{Zn}, \mathrm{Ag}$ salts & Fishtail palm seeds & $\begin{array}{l}\text { Incorporation of metal nanoparticles } \\
\text { Antibacterial effects observed }\end{array}$ & Bacteria (gram $+/-$ ) & N/A & $\mathrm{N} / \mathrm{A}$ & [87] \\
\hline & Mixing with AgNP & Sugarcane bagasse & $\begin{array}{l}\text { Incorporation of } 35 \mathrm{~nm} \text { AgNP } \\
\text { Retained adsorption capacity for small organics } \\
\text { Antibacterial effects observed }\end{array}$ & Escherichia coli & N/A & N/A & [69] \\
\hline & $\begin{array}{l}\text { Calcination of metal salts } \\
\left(3500^{\circ} \mathrm{C}, 3 \text { h) }\right. \\
\text { (i) } \mathrm{Al}_{2} \mathrm{O}_{3} \\
\text { (ii) } \mathrm{TiO}_{2} \\
\text { (iii) } \mathrm{Fe}_{2} \mathrm{O}_{3}\end{array}$ & Not specified & $\begin{array}{l}\text { Incorporation of metal oxide nanoparticles }\left(\mathrm{Al}_{2} \mathrm{O}_{3} \text {, }\right. \\
\left.\mathrm{TiO}_{2}, \mathrm{Fe}_{2} \mathrm{O}_{3}\right)\end{array}$ & Phenol & 1.51 & $\begin{array}{l}\text { (i) } 3.546 \\
\text { (ii) } 3.153 \\
\text { (iii) } 3.288\end{array}$ & [88] \\
\hline & $\begin{array}{l}\mathrm{O}_{2} \text { plasma treatment } \\
\text { Mixing with AgNP }\end{array}$ & Not specified & $\begin{array}{l}\text { Increased hydrophilicity of } \mathrm{AC} \text { by } \mathrm{O}_{2} \text { plasma treatment } \\
\text { Incorporation of } 28 \mathrm{~nm} \text { AgNP } \\
\text { Antibacterial effects observed }\end{array}$ & E. coli & N/A & $\mathrm{N} / \mathrm{A}$ & [70] \\
\hline & $\begin{array}{l}\mathrm{MW} \text { synthesis and impregnation of } \\
\mathrm{TiO}_{2} \text { nanoparticles }\end{array}$ & Not specified & $\begin{array}{l}\mathrm{TiO}_{2} \text { impregnation enabled UV photocatalyzed } \\
\text { degradation of humic acid, resulting in higher } \\
\text { adsorption capacity }\end{array}$ & Humic acid & 6.24 & 9.06 & [89] \\
\hline & $\begin{array}{l}\text { Reduction of metal salts } \\
\text { (i) } \mathrm{Fe} \\
\text { (ii) } \mathrm{Cu} \\
\text { (iii) } \mathrm{Al}\end{array}$ & Not specified & Decrease in specific surface area for modified ACs & Ceftazidime & N/A & $\begin{array}{l}\text { (i) } 161.3 \\
\text { (ii) } 200 \\
\text { (iii) } 172.4\end{array}$ & [90] \\
\hline & $\begin{array}{l}\mathrm{Fe}_{2} \mathrm{O}_{3} \mathrm{NP} \text { impregnation via } \mathrm{MW} \\
\text { hydrothermal }\end{array}$ & Charcoal & $\begin{array}{l}\text { Decrease in overall surface area } \\
\text { Small increase in mesopore volume }\end{array}$ & $\operatorname{Ar}(\mathrm{V})$ & N/A & 27.78 & [67] \\
\hline & CuS NP impregnated AC & Not specified & $\begin{array}{l}\text { Composite adsorbent exhibits high surface area and } \\
\text { high porosity }\end{array}$ & Methyl orange & N/A & 122 & [91] \\
\hline
\end{tabular}

Abbreviations: MW—Microwave, PZC—Point zero charge, NP—Nanoparticle, MB—Methylene blue, N/A—Not applicable. * Adsorption on Bio-char. 


\subsection{Biologically Activated Carbon for Water Purification}

Research into biologically activated carbon (BAC) water purification for the improved removal of DOM and other organic contaminants has shown promising results for delivering cleaner water $[92,93]$. Biologically activated carbon filters are produced when specific bacteria are introduced and become entrapped within the AC porous matrix [94]. Under optimal conditions and with the appropriate organic nutrients, the bacteria can then multiply and populate the surface of the AC. When the BAC is exposed to water containing organic matter and in particular, complex macromolecular organic compounds, these species adsorb to the $\mathrm{AC}$ and the bacteria can biodegrade them into $\mathrm{CO}_{2}$, water and simpler organic compounds. These degradation products can then be easily adsorbed to the AC surface and removed from the water [95]. Commonly, ozone or UV treatment is applied to the dissolved contaminants prior to BAC filtration [96]. An increased removal of THMs and HAAs of $40 \%$ and $30 \%$ respectively was observed when applying an ozone or UV pre-treatment prior to BAC filtration [92]. This process generates highly reactive species within the organic compounds increasing their bioavailability and ease of biodegradation by bacteria. Granular activated carbon inoculated with different strains of heterotrophic nitrifying bacteria showed an improved removal efficiency for ammonia, of 2.8-4 fold increase when compared to non-inoculated GAC [97]. A pilot study involving BAC filters in a water treatment plant has identified their effectiveness for the removal of THMs and HAAs, with greater that $45 \%$ and $80 \%$ removal efficiency for each respectively $[98,99]$. An improved removal of assimilable organic carbon has also been reported using BAC filters, which has implications for the growth of microorganisms in water [93]. The effectiveness of these materials depends on many environmental factors including temperature, $\mathrm{pH}$ and total DOM, which may limit their applicability in some situations.

One of the main drawbacks of BAC is the accumulation of biomass within the material, which must be periodically removed in order to maintain optimal performance. Thermal treatment and various chemical processes have been applied to regenerate the BAC, but these processes have significant drawbacks, including loss of AC structure and the use of hazardous chemicals. As a viable alternative, low frequency ultrasound has been presented as a novel method to regenerate BAC filters [100]. In this approach the regenerated BAC recovered the ability to remove dyes and ammonium from aqueous solutions.

\subsection{Emerging Methods to Improve Water Purification Using Activated Carbon}

The incorporation of highly specific chemical functionality onto the AC surface has afforded adsorbent materials that have a high selectivity for specific contaminant species. One such example is the grafting of cyclodextrin to AC for the selective capture of the pesticide chlordecone [101]. A host-guest complex is formed between the cyclodextrin and chlordecone and the composite material yields an adsorption capacity that is $15 \%$ higher than native AC. The development of composite particle-based adsorbents has also been demonstrated as cellulose beads combined with magnetic nanoparticles and AC. These particles have shown high adsorption performance towards copper, lead and zinc, with adsorption capacities of $45.57,37.99$ and $20.8 \mathrm{mg} / \mathrm{g}$ respectively [102]. A further advantage of this particle system is the ability to magnetically separate the particles from treated water. Another particle adsorbent system, based on a spherical Janus particle configuration (where each hemisphere is differently functionalized), combining AC and Pt functionalities has also been realized. In this case, Janus type particles that have a self-propulsion ability (due to the catalytic capacity of the $\mathrm{Pt}$ ), have shown a high adsorption efficiency for certain heavy metals, explosives and dyes, where over $90 \%$ adsorption was observed in a 5 min timeframe [103]. While particle systems are not practical for POU water purification, they may find use in water treatment plants where their sedimentation and removal is possible. 


\section{Carbon Nanotube Based Water Purification Technology}

\subsection{Carbon Nanotube Adsorption Properties and Target Species}

Since gaining intense interest in the electronics and semiconductor industries, CNTs are now finding novel applications in many other fields. The idea of using CNTs for water filtration has been postulated for over a decade with research focused on using CNTs as nano membrane filters for selective water transport $[104,105]$. This phenomenon is currently being widely investigated as an alternative to polymeric membranes for desalination, with CNTs materials offering the advantages of reduced size and improved water permeability $[106,107]$. Recently research however, into the use of CNTs and CNT composite materials as enhanced adsorbents for contaminant sequestration from water has shown promising results [108].

Carbon nanotubes have similarities to AC in the bonding structure of the carbon backbone and the relative ease of chemical modification. In the context of adsorbing contaminant species however, CNTs exhibit a high available surface area due to their nanoscale, as well as a high proportion of accessible micropores in their aggregated form [109]. There is also a large degree of scope for fabricating composite materials of CNTs, including embedded polymers, nanoparticle grafted CNTs and electrospun fibers [110-112]. The two main forms of CNTs, namely single walled carbon nanotubes (SWCNTs) and multi walled carbon nanotubes (MWCNTs), also allow further flexibility when designing water filtration and purification materials. Each of these forms has been demonstrated as effective adsorbent materials for specific chemical species [113,114].

Carbon nanotubes exhibit similar adsorption mechanisms to AC, through physical adsorption and interaction of specific chemical functionality with the graphite like carbon lattice [115]. While interaction of compounds with $\mathrm{AC}$ requires diffusion into the porous structure, internal diffusion is often not a limiting factor for compounds to interact with CNTs. Adsorption to the surface of CNTs, especially for larger compounds, will be the primary site of interaction. In an aggregated form, CNTs will also present internal meso and micro pore adsorption sites, suitable for smaller species to interact with [116]. The proportion of opened or closed CNTs also has a significant impact on the overall adsorption capacity of the material and is likely linked to the available surface area and chemical functional groups that are generated during CNT opening and cutting reactions $[108,117]$.

One attractive property of CNTs for water purification is their increased capacity to remove heavy metals from solution compared to AC [118-120]. Available surface area and surface functional groups are the key determining factors that influence this improved adsorption and these parameters have been the focus of much research [121]. The use of CNTs to remove heavy metals from water is one of the most widely investigated applications in this field [122]. The filtration and removal of organic contaminants including dyes, DOM and pharmaceuticals by CNTs has also garnered increased interest in recent times $[113,123-125]$.

\subsection{Chemical Modifications and Composite Materials of Carbon Nanotubes for Enhanced Water Contaminant Removal}

As with AC, chemical modifications of CNTs has been shown to improve their adsorption capacity and selectivity to various contaminant species. Recently published research on the performance of CNTs for water purification are presented in Table 3. Adsorption and purification results for modified CNTs as well as polymer composites, metal nanoparticle impregnated, membrane infused and electrospun fibres are also outlined in Table 3.

Due to the similar chemical structure between CNTs and AC, oxidative acid treatment by $\mathrm{HNO}_{3}$ or $\mathrm{H}_{2} \mathrm{SO}_{4}$ is a common method for introducing or modifying the surface functional groups and serves two main purposes [126]. The first purpose is to open the ends of the CNTs and to shorten or cut the tubes [127]. This increases the surface area of the CNTs and can help to homogenise the CNT mixture allowing for more precise control over the physical properties. The second effect of acid treatment is to introduce oxidative functional groups (carboxylic acids, alcohols, epoxides) along the edges of the CNTs 
and particularly around the openings, which enables the CNTs to be further chemically modified [128]. Shortening the tube length and addition of polar functional groups also enables the CNTs to be more easily dispersed in aqueous solutions. Acidification of CNTs and subsequent modification with an ionic liquid has enabled the adsorption of $\mathrm{Cr}(\mathrm{VI})$ from solution at $85.83 \mathrm{mg} / \mathrm{g}$ [129]. $\mathrm{HNO}_{3}$ treatment of MWCNTs followed by combination with iron oxide nanoparticles has afforded a composite material with adsorption capacities for the dyes methylene blue, neutral red and brilliant cresyl blue of 74.23, 55.17 and $62.35 \mathrm{mg} / \mathrm{g}$ respectively [130]. There is however an optimal oxidation extent for CNTs to achieve maximum adsorption capacity, with $3.2 \%$ (oxidation) reported for optimal adsorption of the antibiotic tetracycline [131].

Introduction of specific functional groups not only has the beneficial effect of enhanced adsorption for certain species, but also allows the CNTs to be easily incorporated into composite materials. Commonly, CNTs are combined with different polymers to form water permeable composites, with the capacity for adsorbing contaminant species or filtering particulate matter. Polymers that have been used to form CNTs composites include chitosan, polyacrylamide, polysulfone and polyaniline, each of which have been tailored for specific applications and target contaminant species [132-135]. The performance of these CNT-polymer composites is summarized in Table 3.

Along with polymer composites, CNTs have been combined with solid support materials including silica, aluminum and ceramics to facilitate water filtration and purification [136-138]. The introduction of metallic nanoparticles along the CNTs has also been studied for similar applications as in AC. Various metal/metal oxide nanoparticles $\left(\mathrm{Cu}, \mathrm{Fe}_{3} \mathrm{O}_{4}, \mathrm{Ag}\right)$ have been shown to enhance adsorption of specific species including heavy metals and dyes [139,140].

Another promising water purification method using CNTs involves vertically aligned CNT (VA-CNT) array membranes. Theoretical and practical studies have indicated high water flow through VA-CNTs membranes, with the hope to improve on current nano- and ultrafiltration materials [141]. The VA-CNT arrays are usually prepared by fabricating VA-CNTs on a solid or porous support and infiltrating a non-permeable polymer (epoxy, urethane) around the CNTs to hold them in position $[142,143]$. Most of the research into VA-CNT membranes has been associated with desalination, however the physical rejection of organic contaminant species has also been investigated [144,145]. The current efficiency, stability and long term performance have limited the widespread application of VA-CNT membranes, however this system may prove applicable in combination with one or more of the water purification materials discussed in this review.

Due to their conductive properties, certain CNT composites have also proven effective in the removal of some dyes and pharmaceutical compounds from water through electrochemical oxidative breakdown and adsorption [146,147]. In this process a bias is applied across the composite material, while the contaminated water is passed through the membrane. Interactions between the CNTs and contaminant species causes direct electron transfer and subsequent oxidative degradation, followed by adsorption of the breakdown products onto the CNTs. The presence of natural organic matter however has a negative effect on the removal of tetracycline, due to competitive adsorption to CNTs [148]. As discussed in the following section, this purification method has also been applied for the inactivation of viruses in contaminated water [149].

While the cost of producing and modifying CNTs has dramatically reduced in recent years, this form of carbon is not currently widely used for water filtration. Issues with the potential environmental release and toxicity of the CNTs themselves has hindered their implementation into commercial water purification devices. It is likely that POU water purification systems that utilize CNTs will be based around the types of composite materials that have been discussed here. Polymer supported CNT membranes provide the advantage of mechanical strength and desirable properties with the ability to upscale production. More work must be done to address the environmental concerns associated with CNTs and also the practical consideration such as competitive adsorption between multiple contaminant species. 


\subsection{Carbon Nanotube Materials for Antimicrobial and Antibiofouling Water Purification Applications}

One of the promising applications of CNTs in water purification is for the neutralization of bacteria and virus or the exclusion of these species from water via nanofiltration. A further desirable property for advanced water purification materials is an antifouling capacity in order to prevent the adhesion of bacteria and biofilm formation. Various CNT composite materials have been investigated in order to achieve both neutralization and antifouling water purification platforms.

Due to the nanoscale features of CNTs, this material presents as a promising means to generate size exclusion membranes, capable of blocking the transport of certain microorganism across the membrane. Aggregated CNTs deposited onto a porous polymer membrane can effectively filter bacteria from aqueous solutions, where the amount of CNT loading also has an effect on virus filtration capacity [150]. A more elaborate example of a CNT membrane for bacteria and virus filtration has been fabricated as polymer bound, vertically aligned CNTs that enable size exclusion of sub $5 \mathrm{~nm}$ materials [110].

Resistance to bacterial adhesion by self-supported CNT membranes was observed, with the resistance attributed to an effect of the surface roughness at the nanoscale [143]. An epoxy entrapped vertically aligned CNT material has displayed similar antibiofouling properties with physical damage and oxidative stress to microorganisms proposed as the mechanisms of action [151]. A more direct approach to fabricate antibacterial CNT water purification membranes has been realized by the incorporation of the natural bactericide nisin, through adsorption onto the CNTs [152]. The nisin adsorbed CNTs were then coated onto a polycarbonate filter membrane where bacteria would become entrapped and then neutralized.

\subsection{Point-of-Use Water Purification Devices Based on Carbon Nanotubes}

Cost of synthesis and device manufacture will likely prohibit the development of standalone CNT POU water purification devices in the short to medium term, however the effectiveness of this material cannot be understated. Carbon nanotubes increased capacity for the adsorption of contaminant metal ions (over AC) and the ability to fabricate complex composite materials that impart novel and advantageous properties, highlight CNTs future in water purification. As discussed for AC, competitive adsorption analysis must be performed on these materials, however in the short term it is likely that CNT composites could be incorporated into AC POU devices for the highly targeted removal of specific water contaminant species. The material's electrical conductivity properties should also enable an enhanced removal of certain species when coupled to traditional AC POU devices. Finally, the promising antimicrobial properties that can be imparted to CNT composites will be highly beneficial in situations where access to treated water is limited. While certain questions remain to be answered, such as CNTs leaching from devices, it is clear that this material and its composites have a clear role in water purification and POU devices more specifically. 
Table 3. Carbon nanotube modifications, composites and water purification properties.

\begin{tabular}{|c|c|c|c|c|c|}
\hline CNT & $\begin{array}{l}\text { Materials and Modification to } \\
\text { CNT }\end{array}$ & Method & Target Species & Performance & Ref. \\
\hline \multirow[t]{6}{*}{ Native } & MWCNT/SWCNT sponges & $\begin{array}{l}\text { Flow } \\
\text { Adsorption }\end{array}$ & Polychlorinated biphenyls & $81-119 \%$ recovery from real sample & {$[153$} \\
\hline & SWCNT membrane & $\begin{array}{l}\text { Batch } \\
\text { Photodegradation } \\
\text { induced adsorption }\end{array}$ & Rhodamine B & $\begin{array}{l}190 \mathrm{mg} / \mathrm{g} \text { adsorption }(1.3 \text { times higher than best } \\
\text { performing carbon materials }\end{array}$ & {$[154$} \\
\hline & MWCNTs & $\begin{array}{l}\text { Batch } \\
\text { Adsorption }\end{array}$ & THMs & $\begin{array}{l}\text { Adsorption capacities of } 10.98,6.85,6.57 \text {, and } \\
5.95 \mathrm{mg} / \mathrm{g} \text { for } \mathrm{CHCl}_{3}, \mathrm{CHCl}_{2} \mathrm{Br}, \mathrm{CHClBr}_{2} \text {, and } \mathrm{CHBr}_{3} \\
\text { respectively }\end{array}$ & {$[155$} \\
\hline & Acid treated MWCNTs & $\begin{array}{l}\text { Batch } \\
\text { Adsorption }\end{array}$ & Tetracycline & $253.38 \mathrm{mg} / \mathrm{g}$ adsorption & {$[156$} \\
\hline & $\begin{array}{l}\text { (i) Pristine MWCNTs } \\
\text { (ii) COOH-MWCNTs } \\
\text { (iii) } \mathrm{NH}_{2} \text {-MWCNTs }\end{array}$ & $\begin{array}{l}\text { Batch } \\
\text { Adsorption }\end{array}$ & $\begin{array}{l}\text { 1,8-Dichlorooctane, quinolone, } \\
\text { alkylphenoletoxilate }\end{array}$ & $\begin{array}{l}\text { Adsorption of target species affected by CNT } \\
\text { functional groups and relative hydrophobicity of each }\end{array}$ & {$[157$} \\
\hline & $\mathrm{HNO}_{3}$ treated CNTs & $\begin{array}{l}\text { Batch } \\
\text { Adsorption }\end{array}$ & $\mathrm{Cd}(\mathrm{II})$ & $\begin{array}{l}\text { Acid treated CNTs showed higher adsorption capacity } \\
\text { than acid treated AC, carbon nanofibers and fly ash } \\
\text { Greater than } 95 \% \text { removal of Cd(II) by CNTs }\end{array}$ & [77] \\
\hline \multirow[t]{6}{*}{ Polymer composite } & $\begin{array}{l}\text { Acid treated MWCNTs + } \\
\text { chitosan }\end{array}$ & Electrosorption & Aniline & $26.4 \mathrm{mg} / \mathrm{g}$ adsorption & {$[132$} \\
\hline & $\begin{array}{l}\text { Hydroxylated MWCNTs + } \\
\text { PANI + PES }\end{array}$ & $\begin{array}{l}\text { Flow } \\
\text { Size exclusion } \\
\text { Adsorption }\end{array}$ & Humic acid & $\begin{array}{l}80 \% \text { removal of humic acid } \\
\text { High water flux }\end{array}$ & [135 \\
\hline & SWCNTs + parylene membrane & $\begin{array}{l}\text { Flow } \\
\text { Size exclusion }\end{array}$ & $\begin{array}{l}\text { Direct Blue } 71, \mathrm{AuNP}, \\
\text { Dengue virus }\end{array}$ & $\begin{array}{l}\text { High water flux } \\
\text { Rejection of } \geq 5 \mathrm{~nm} \text { species }\end{array}$ & {$[110$} \\
\hline & SWCNTs + Kevlar nanofibers & $\begin{array}{l}\text { Batch } \\
\text { Adsorption }\end{array}$ & $\begin{array}{l}\text { Phenylic compounds, heavy } \\
\text { metals, dyes }\end{array}$ & $\begin{array}{l}\text { Composite material displayed higher adsorption } \\
\text { capacity for all compounds, when compared to } \\
\text { polyethersulfone and polysulfone adsorbents }\end{array}$ & {$[158$} \\
\hline & $\begin{array}{l}\text { CNT/silica nanoparticle } \\
\text { sponges }\end{array}$ & $\begin{array}{l}\text { Batch } \\
\text { Adsorption }\end{array}$ & Oils, organic solvents & $\begin{array}{l}\text { High adsorption capacity to oils and solvents, up to } \\
1885 \text { weight } \%\end{array}$ & {$[136$} \\
\hline & $\mathrm{MWCNT} / \mathrm{TiO}_{2} /$ polysulfone & $\begin{array}{l}\text { Flow } \\
\text { Adsorption } \\
\text { Exclusion }\end{array}$ & Humic acid & $\begin{array}{l}\text { Composite outperformed native polysulfone material } \\
\text { in terms of both adsorption/rejection of humic acid } \\
\text { and water permeability } \\
\text { Composite was flexible for different concentrations of } \\
\text { humic acid }\end{array}$ & [133 \\
\hline
\end{tabular}


Table 3. Cont

\begin{tabular}{|c|c|c|c|c|c|}
\hline CNT & $\begin{array}{l}\text { Materials and Modification to } \\
\text { CNT }\end{array}$ & Method & Target Species & Performance & Ref. \\
\hline \multirow[t]{3}{*}{$\begin{array}{l}\text { Metal nanoparticle } \\
\text { composite }\end{array}$} & $\begin{array}{l}\text { Acid activated MWCNTs + } \\
\mathrm{TiO}_{2} \text { nanoparticles }\end{array}$ & $\begin{array}{l}\text { Batch } \\
\text { Photocatalyzed } \\
\text { degradation }\end{array}$ & 4-Chlorophenol & $\begin{array}{l}\text { Two fold increase in photocatalyzed degradation with } \\
\text { MWCNTs }\end{array}$ & [159] \\
\hline & $\begin{array}{l}\mathrm{MWCNTs}+\mathrm{Graphene}+\mathrm{Fe}_{3} \mathrm{O}_{4} \\
\text { nanoparticles }\end{array}$ & $\begin{array}{l}\text { Batch } \\
\text { Flow } \\
\text { Adsorption }\end{array}$ & $\operatorname{Ar}(\mathrm{III})$ and $(\mathrm{V})$ & $\begin{array}{l}\text { Flow outperformed batch adsorption for removal of } \\
\operatorname{Ar}(\mathrm{III}) \text { and } \operatorname{Ar}(\mathrm{V}), 100 \% \text { and } 74 \% \text { removal respectively }\end{array}$ & [160] \\
\hline & $\begin{array}{l}\text { Carrageenan modified acid } \\
\text { treated MWCNTs }+\mathrm{Fe}_{3} \mathrm{O}_{4} \\
\text { nanoparticles }\end{array}$ & $\begin{array}{l}\text { Batch } \\
\text { Adsorption }\end{array}$ & Methylene blue & $\begin{array}{l}\text { Carrageenan modified MWCNT composites } \\
\text { outperformed non-carrageenan } \\
\text { Composite could be magnetically separated }\end{array}$ & [139] \\
\hline \multirow[t]{5}{*}{ Filter membrane infused } & $\begin{array}{l}\text { PVDF membrane + } \\
\text { (i) Native MWCNTs } \\
\text { (ii) Hydroxylated MWCNTs } \\
\text { (iii) Animated MWCNTs } \\
\text { (iv) Large inner diameter } \\
\text { MWCNTs }\end{array}$ & $\begin{array}{l}\text { Flow } \\
\text { Adsorption }\end{array}$ & $\begin{array}{l}\text { Triclosan, prometryn, } \\
\text { 4-acetylamino-antipyrine, } \\
\text { carbendazim, caffeine, ibuprofen, } \\
\text { acetaminophen }\end{array}$ & $\begin{array}{l}\text { Highest adsorption performance observed for } \\
\text { hydroxylated MWCNTs } \\
\text { High specific surface area improved performance }\end{array}$ & [113] \\
\hline & $\begin{array}{l}\text { PTFE membrane + } \\
\text { (i) Pristine MWCNTs } \\
\text { (ii) COOH-MWCNTs }\end{array}$ & $\begin{array}{l}\text { Flow } \\
\text { Electrochemical } \\
\text { degradation } \\
\text { Adsorption }\end{array}$ & Ibuprofen & $\begin{array}{l}\text { Near } 100 \% \text { removal of target with } 2 \mathrm{~V} \text { bias } \\
\text { Higher adsorption performance by COOH-MWCNT } \\
\text { membrane, due to increased surface area and } \\
\text { hydrophilic chemistry }\end{array}$ & [161] \\
\hline & PVB fiber + oxidized MWCNTs & $\begin{array}{l}\text { Flow } \\
\text { Ultrafiltration }\end{array}$ & $\begin{array}{l}\text { BSA } \\
\text { Humic acid }\end{array}$ & $\begin{array}{l}\text { Improved filtration performance by MWCNT } \\
\text { embedded fibers }\end{array}$ & [162] \\
\hline & Porous alumina $+\mathrm{CNTs}$ & $\begin{array}{l}\text { Flow } \\
\text { Adsorption }\end{array}$ & Humic acid & $\begin{array}{l}\text { High initial water flux capacity } \\
\text { Strong adsorption of humic acid, led to decline in flux }\end{array}$ & [145] \\
\hline & $\begin{array}{l}\text { MWCNT network supported } \\
\text { on PTFE membrane }\end{array}$ & $\begin{array}{l}\text { Flow } \\
\text { Electrochemical } \\
\text { degradation } \\
\text { Adsorption }\end{array}$ & Tetracycline & $\begin{array}{l}\text { High degradation and removal efficiency of MWCNT } \\
\text { electrochemical filter } \\
\text { Performance was negatively effected by the presence } \\
\text { of natural organic matter }\end{array}$ & [148] \\
\hline Electrospun fiber & $\begin{array}{l}\text { Carbon nanofiber of } \\
\text { polyacrylonitrile + MWCNTs }\end{array}$ & $\begin{array}{l}\text { Flow } \\
\text { Adsorption }\end{array}$ & Atrazine, sulfmethoxazole & $\begin{array}{l}\text { Comparable adsorption capacity to AC, faster } \\
\text { adsorption kinetics }\end{array}$ & [163] \\
\hline
\end{tabular}

Abbreviations: PVDF-polyvinylidene fluoride, PANI—polyaniline, PES—polyethersulfone, AuNP—gold nanoparticle, PVB—poly(vinyl butyral), BSA—bovine serum albumin, PTFE-Polytetrafluoroethylene. 


\section{Graphene-Based Materials for Water Purification}

\subsection{Properties of Graphene and Graphene Oxide}

Graphene is considered a two dimensional material and exists as sheets of a single layer of graphitically bonded carbon atoms [164]. Like CNTs, this material has received attention from the electronics industry due to attractive conductivity and thermal resistance properties, with application in circuitry, solar cells and batteries under investigated [165,166].

In the context of water purification, graphene presents as an interesting carbon material that offers certain advantages over AC and CNTs. The high available surface area for contaminant species to adsorb to, as well as the potential for exotic chemical modifications and composite fabrication make graphene an attractive material to use for water purification [167]. Much like CNTs, a considerable amount of research on graphene for water purification has focused on nano-perforated graphene sheets as size exclusion filtration membranes [168]. Graphene adsorbents and antibacterial materials have recently been explored as more advanced alternatives to AC for water purification $[169,170]$.

For water purification applications, graphene is usually converted into graphene oxide (GO) via an acid treatment process, namely the Hummers or improved Hummers methods [14]. This conversion to GO introduces a high number of hydrophilic oxygen containing groups across the graphene sheet, including hydroxyls and epoxides [171]. The most profound effect of the chemical modification is to markedly increase water flow through GO materials due to an increase in hydrophilicity, enabling the formation of membranes with high water permeability and flux [172]. The water permeability effect has been exploited by the fabrication of laminar structures from GO, which act as selective or exclusion membranes without the need for controlled nano-perforation of the graphene sheets [173]. Water purification applications using this platform are currently being investigated, with results demonstrating that these structures are capable of filtering organic compounds of various sizes. Filtration of dyes has been achieved, where acid brilliant blue, chrome blue-black and methyl orange were rejected by the filter at $98.2 \%, 95.2 \%$ and $73.4 \%$ respectively [174]. A chemically cross-linked analogue of the graphene laminar structure has also shown up to $34.3 \%$ rejection of dissolved organic carbon [175]. Such laminar structures also have the capacity for graphene to act as an adsorbent material and antibacterial agent, which is of particular interest in water purification, with the material performing to a high capacity in both applications $[176,177]$.

\subsection{Water Purification Mechanisms Using Graphene and Specific Targeted Species}

The purification mechanisms of graphene and GO composite materials can be separated based on the type of material or composite. There are adsorbent graphene materials that rely on a similar mechanism for adsorbing contaminant species as AC and CNTs. Electrostatic, hydrogen bonding and $\pi-\pi$ interactions between contaminant species and the graphene material all contribute to the material's excellent adsorption capacity [178]. Further to the chemical properties, the high specific surface area (over $1000 \mathrm{~m}^{2} / \mathrm{g}$ ) of this 2D material facilitates excellent adsorption capacity [179]. Secondly are the nano-filtration GO membranes that rely on exclusion of contaminants to deliver purified water, including the laminar structures and nano-perforated membranes previously mentioned. Molecular dynamic studies have been performed to assess the ability of nanoporous graphene to purify water of trihalomethanes [180]. Recent research has extended the idea of the laminar structure by confining the hydration related swelling of the layered graphene and flowing a solution parallel through the laminar structure [181]. This system has been specifically designed for the rejection of ions and desalination purposes however control over the pore diameter introduces the possibility for the filtration of different contaminant species. Finally, graphene materials and composites for neutralizing microorganisms function through different mechanisms, with the graphene effecting or disrupting the biological function of these species and inactivating them. The hypothesized antibacterial mechanisms of action include penetration and compromization of the bacteria membrane, generation of reactive oxygen species (ROS) and envelopment of microorganisms [177,182,183]. Composites of silver nanoparticle decorated GO deposited onto cellulose acetate membranes have also proven effective 
as antibacterial agents, where inhibition of bacterial growth and prevention of biofilm formation has been observed [184].

\subsection{Emerging Composite Graphene Materials for Enhanced Water Purification}

Due to the scale and current high cost of producing graphene, composite materials are often fabricated that contain a percentage of graphene or GO. These composites provide a high filtration ability and appropriate physicochemical properties (i.e., mechanical strength, magnetism, hydrophilicity, etc). Similar to CNTs, graphene has been combined with metal nanoparticles such as silver, iron oxides and $\mathrm{TiO}_{2}$ to impart antibacterial, heavy metal ion and organics affinity respectively. An iron oxide/non-oxidative graphene/CNT composite gave a maximum adsorption capacity for $\mathrm{As}(\mathrm{III})$ and $\mathrm{As}(\mathrm{V})$ as 9.11 and $5.21 \mathrm{mg} / \mathrm{g}$ respectively [160]. The removal of over $98 \%$ humic acid from water was achieved using a novel $\mathrm{TiO}_{2}$ nanowire/iron oxide nanoparticle/GO composite, where the iron oxide facilitated humic acid adsorption and the combination of $\mathrm{TiO}_{2}$ nanowires and $\mathrm{GO}$ allowed photocatalytic degradation of the species [185]. The combination of silver nanoparticles and GO sheets has enabled the fabrication of a highly effective antibacterial material [186].

The combination of graphene with various polymers or the deposition of graphene sheets onto solid micro or ultra-filtration membrane supports has also allowed the development of promising materials for water filtration and purification applications. Chitosan has been used with GO to prepare adsorbent hydrogel materials that have affinities for both cationic and anionic dyes, as well as heavy metals. The adsorption capacities of the dyes methylene blue and Eosin $\mathrm{Y}$ were reported as greater than $300 \mathrm{mg} / \mathrm{g}$, while the adsorption of $\mathrm{Cu}$ (II) and $\mathrm{Pb}$ (II) were found to be $70 \mathrm{and} 90 \mathrm{mg} / \mathrm{g}$ respectively [187]. A more complex material for the adsorption of $\mathrm{Pb}(\mathrm{II})$ has been realized by the combination of magnetic chitosan and GO that was imprinted with $\mathrm{Pb}$ (II) ions. Removal of the imprint ion and subsequent re-adsorption from solution gave a maximum adsorption capacity of $79 \mathrm{mg} / \mathrm{g}$ [188]. The inclusion of magnetic properties in this material also allowed the adsorbate to be easily separated from aqueous solution. The application of a polydopamine/GO hydrogel composite has afforded adsorption capacities for $\mathrm{Pb}(\mathrm{II})$ and $\mathrm{Cd}(\mathrm{II})$ of 336.32 and $145.48 \mathrm{mg} / \mathrm{g}$ respectively, while also facilitating the adsorption of the dye species Rhodamine B $(207.06 \mathrm{mg} / \mathrm{g})$ and $p$-nitrophenol $(260.38 \mathrm{mg} / \mathrm{g})$ [189]. A one-step hydrothermally assembled aerogel graphene and CNT composite has also been used for removal of the dye methylene blue from aqueous solution, with $97 \%$ of the dye captured by the material [190].

The deposition of GO or nitrogen doped GO onto a $\mathrm{TiO}_{2} / \mathrm{ZrO}_{2}$ ceramic membrane has demonstrated the effect of the GO thickness on water flux and also shown the nitrogen doped GO as a potential materials for the preparation of an electrodegradation membrane [191]. Another application of supported GO membranes has been shown, where polydopamine coated polysulfone was used as the solid support to fabricate a cross-linked GO network. This membrane provided a moderate rejection of the dye methylene blue (46-66\%) and a high rejection of the dye Rhodamine WT (93-95\%) [172]. In each case, these graphene composites have generally been investigated for the removal or adsorption of one target species, or multiple targets analysed individually. One study however has investigated the simultaneous adsorption of heavy metals and inactivation of bacteria using a multi-component composite material of GO, CNTs and the antimicrobial peptide PGLa. Results indicated a near 100\% removal of bacteria and over $95 \%$ removal of $\mathrm{As}(\mathrm{III})$ and $\mathrm{Pb}$ (II) [192]. The adsorption performance of the above mentioned graphene composite materials are summarized in Table 4.

Further to the two or three component graphene composites, more complex materials are being developed. Aerogels of graphene coated, chemically modified silica diatoms, impregnated with iron nanoparticles have shown a high affinity towards mercury ions, with an adsorption capacity of $>500 \mathrm{mg} / \mathrm{g}$ [193]. The fabrication of GO-microbots, consisting of layers of GO, nickel and platinum have been used as environmental clean-up agents for the removal of lead from water, where depending on the GO-microbot dose, up to $95 \%$ removal of lead was observed [194]. In this case, the GO can capture lead from solution, while the platinum allows added hydrogen peroxide to be converted to $\mathrm{H}_{2(\mathrm{~g})}$ and $\mathrm{O}_{2(\mathrm{~g})}$ that act as propellants and the nickel facilitates magnetic control of the microbots. 
Table 4. Target species and performance of graphene-based water filtration materials.

\begin{tabular}{|c|c|c|c|c|}
\hline Target Class & Specific Compound(s) & Graphene Material Properties & Adsorption Capacity (mg/g) & Ref. \\
\hline \multirow[t]{8}{*}{ Heavy metals } & $\begin{array}{l}\text { (i) } \mathrm{Cu} \\
\text { (ii) } \mathrm{Pb} \\
\text { (iii) } \mathrm{Cd}\end{array}$ & Sulfydryal modified GO/chitosan composite & $\begin{array}{l}\text { (i) } 425 \\
\text { (ii) } 447 \\
\text { (iii) } 177 \\
\end{array}$ & [110] \\
\hline & $\begin{array}{l}\text { (i) } \mathrm{Cu} \\
\text { (ii) } \mathrm{Mn}\end{array}$ & Surfactant modified graphene & $\begin{array}{l}\text { (i) } 369.16 \\
\text { (ii) } 223.67\end{array}$ & [195] \\
\hline & $\mathrm{Pb}$ & GO and manganese oxide NPs & 553 & [196] \\
\hline & $\begin{array}{l}\text { (i) } \mathrm{Ni} \\
\text { (ii) } \mathrm{Pb} \\
\text { (iii) } \mathrm{Zn}\end{array}$ & Cross-linked GO on porous ceramic support & $>95 \%$ rejection & [197] \\
\hline & $\begin{array}{l}\text { (i) } \operatorname{As}(\mathrm{III}) \\
\text { (ii) } \mathrm{As}(\mathrm{V})\end{array}$ & $\mathrm{Fe}_{3} \mathrm{O}_{4} /$ non-oxidative graphene/CNT composite & $\begin{array}{l}\text { (i) } 9.11 \\
\text { (ii) } 5.21\end{array}$ & [160] \\
\hline & $\begin{array}{l}\text { (i) } \mathrm{Cu} \text { (II) } \\
\text { (ii) } \mathrm{Pb} \text { (II) }\end{array}$ & $\mathrm{GO} /$ chitosan hydrogel & $\begin{array}{l}\text { (i) } 70 \\
\text { (ii) } 90\end{array}$ & [187] \\
\hline & $\mathrm{Pb}(\mathrm{II})$ & Magnetic chitosan/GO composite, imprinted with $\mathrm{Pb}(\mathrm{II})$ & 79 & [188] \\
\hline & $\begin{array}{l}\text { (i) } \mathrm{Pb} \text { (II) } \\
\text { (ii) } \mathrm{Cd} \text { (II) }\end{array}$ & Polydopamine/GO hydrogel & $\begin{array}{l}\text { (i) } 336.32 \\
\text { (ii) } 145.48\end{array}$ & [189] \\
\hline \multirow[t]{4}{*}{ Dyes } & $\begin{array}{l}\text { (i) MB } \\
\text { (ii) Rhodamine B }\end{array}$ & GO hydrogel & $\begin{array}{l}\text { (i) } 7.85 \\
\text { (ii) } 29.44 \\
\end{array}$ & [198] \\
\hline & $\begin{array}{l}\text { (i) } \mathrm{MB} \\
\text { (ii) Eosin } Y\end{array}$ & $\mathrm{GO} /$ chitosan hydrogel & $>300$ & [187] \\
\hline & $\begin{array}{l}\text { (i) Rhodamine B } \\
\text { (ii) p-nitrophenol }\end{array}$ & Polydopamine/GO hydrogel & $\begin{array}{l}\text { (i) } 207.06 \\
\text { (ii) } 260.38\end{array}$ & [189] \\
\hline & $\mathrm{MB}$ & Graphene/CNT aerogel & 81.97 & [190] \\
\hline Pharmaceuticals & Ibuprofen & Ethylene diamine modified GO & 95.2 & [199] \\
\hline DOM & Humic acid & $\mathrm{TiO}_{2}$ nanowire $/ \mathrm{Fe}_{2} \mathrm{O}_{3}$ nanoparticle/GO composite & $>98 \%$ rejection & [185] \\
\hline
\end{tabular}

Abbreviations: $\mathrm{GO} —$ graphene oxide, $\mathrm{MB}$ —methylene blue, NPs—nanoparticles. 


\subsection{Graphene and Graphene Composites for Point-of-Use Devices}

As the most recently discovered of the carbon materials discussed here, many of the graphene materials and composites that have been developed for water purification applications are still in the early research phase, however these materials show significant future potential. The application of graphene in water filtration devices will likely be through integration of the material into existing supports or membranes to enhance the filtration performance. The higher cost of fabrication will limit the production of homogeneous graphene-based filter systems in the short term, with composite materials the likely avenue to commercial devices. Graphene POU devices also face limitations in the short term, related to water flux, membrane stability and robustness. For use in POU water purification devices the potential leaching and health effects of the graphene must also be taken into consideration prior to commercial development.

\section{Conclusions and Future Perspectives}

Carbon-based materials are currently dominating the water filtration research field with adsorbent, size exclusion membrane and antimicrobial systems all described. Correlation between the recent explosion in research output of water purification materials utilizing these carbon frameworks and the increasing level and range of water contaminant species is no coincidence. There is now global recognition that the health of waterways is in decline, with much effort applied to maintaining the effectiveness of water treatment facilities. Ultimately however, individuals will still be exposed to water contaminants that escape (or result from) the treatment process. This will undoubtedly lead to an increased uptake of POU water purification devices. Many of the composite materials that are described in this review will be well suited for small scale filtration systems, which fits for in-home POU water purification applications.

Activated carbon, due to its current cost of manufacture, will remain the most prominent carbon-based water filtration material for the time being, with chemical modifications to improve capture capacity and efficiency maintaining its relevance. As the cost of fabricating CNTs and graphene are reduced, it is highly likely that these carbon nanomaterials will be developed into advanced filtration devices or as additional components to broad spectrum AC POU devices, to capture specific contaminants. For POU water purification, the ability to regenerate the filter is highly advantageous to extend working life and maintain performance. Graphene and CNT materials offer significant advantages over AC for regeneration and this capacity will likely influence the next generation of water purification devices. Effective neutralization of microorganism by CNT and graphene devices also provides advantage over AC and will be directly applicable in situations where access to treated water is limited.

One of the promising aspects of CNT and graphene-based materials for water purification is the relatively low quantity of material required to achieve high adsorption or filtration capacity. In the short term, the combination of existing carbon materials (ACs) with other, emerging nanomaterials or chemistries will be highly relevant in developing the next generation of water filtration and purification materials and devices.

Conflicts of Interest: The authors declare no conflict of interest.

\section{References}

1. Gavrilescu, M.; Demnerová, K.; Aamand, J.; Agathos, S.; Fava, F. Emerging pollutants in the environment: Present and future challenges in biomonitoring, ecological risks and bioremediation. New Biotechnol. 2015, 32, 147-156. [CrossRef] [PubMed]

2. Pal, A.; He, Y.; Jekel, M.; Reinhard, M.; Gin, K.Y.-H. Emerging contaminants of public health significance as water quality indicator compounds in the urban water cycle. Environ. Int. 2014, 71, 46-62. [CrossRef] [PubMed] 
3. Mostofa, K.M.G.; Liu, C.-Q.; Mottaleb, M.A.; Wan, G.; Ogawa, H.; Vione, D.; Yoshioka, T.; Wu, F. Dissolved Organic Matter in Natural Waters; Springer: Berlin/Heidelberg, Germany, 2013; pp. 1-137.

4. Cabral, J.P.S. Water microbiology. Bacterial pathogens and water. Int. J. Environ. Res. Public Health 2010, 7. [CrossRef] [PubMed]

5. Schwarzenbach, R.P.; Escher, B.I.; Fenner, K.; Hofstetter, T.B.; Johnson, C.A.; von Gunten, U.; Wehrli, B. The challenge of micropollutants in aquatic systems. Science 2006, 313, 1072. [CrossRef] [PubMed]

6. Baghoth, S.A.; Sharma, S.K.; Amy, G.L. Tracking natural organic matter (NOM) in a drinking water treatment plant using fluorescence excitation-emission matrices and parafac. Water Res. 2011, 45, 797-809. [CrossRef] [PubMed]

7. Richardson, S.D. Disinfection by-products and other emerging contaminants in drinking water. TrAC Trends Anal. Chem. 2003, 22, 666-684. [CrossRef]

8. Frank, J.; Ruhl, A.S.; Jekel, M. Impacts of backwashing on granular activated carbon filters for advanced wastewater treatment. Water Res. 2015, 87, 166-174. [CrossRef] [PubMed]

9. Gibert, O.; Lefèvre, B.; Fernández, M.; Bernat, X.; Paraira, M.; Pons, M. Fractionation and removal of dissolved organic carbon in a full-scale granular activated carbon filter used for drinking water production. Water Res. 2013, 47, 2821-2829. [CrossRef] [PubMed]

10. Moreno-Castilla, C. Adsorption of organic molecules from aqueous solutions on carbon materials. Carbon 2004, 42, 83-94. [CrossRef]

11. Smith, S.C.; Rodrigues, D.F. Carbon-based nanomaterials for removal of chemical and biological contaminants from water: A review of mechanisms and applications. Carbon 2015, 91, 122-143. [CrossRef]

12. Bhatnagar, A.; Hogland, W.; Marques, M.; Sillanpää, M. An overview of the modification methods of activated carbon for its water treatment applications. Chem. Eng. J. 2013, 219, 499-511. [CrossRef]

13. Sui, Z.; Meng, Q.; Zhang, X.; Ma, R.; Cao, B. Green synthesis of carbon nanotube-graphene hybrid aerogels and their use as versatile agents for water purification. J. Mater. Chem. 2012, 22, 8767-8771. [CrossRef]

14. Han, Y.; Xu, Z.; Gao, C. Ultrathin graphene nanofiltration membrane for water purification. Adv. Funct. Mater. 2013, 23, 3693-3700. [CrossRef]

15. Karumuri, A.K.; Oswal, D.P.; Hostetler, H.A.; Mukhopadhyay, S.M. Silver nanoparticles attached to porous carbon substrates: Robust materials for chemical-free water disinfection. Mater. Lett. 2013, 109, 83-87. [CrossRef]

16. Her, N.; Amy, G.; McKnight, D.; Sohn, J.; Yoon, Y. Characterization of DOM as a function of MW by fluorescence EEM and HPLC-SEC using UVA, DOC, and fluorescence detection. Water Res. 2003, 37, 4295-4303. [CrossRef]

17. Lozovik, P.A.; Morozov, A.K.; Zobkov, M.B.; Dukhovicheva, T.A.; Osipova, L.A. Allochthonous and autochthonous organic matter in surface waters in Karelia. Water Resour. 2007, 34, 204-216. [CrossRef]

18. Stedmon, C.A.; Markager, S. Tracing the production and degradation of autochthonous fractions of dissolved organic matter by fluorescence analysis. Limnol. Oceanogr. 2005, 50, 1415-1426. [CrossRef]

19. King, D.N.; Donohue, M.J.; Vesper, S.J.; Villegas, E.N.; Ware, M.W.; Vogel, M.E.; Furlong, E.F.; Kolpin, D.W.; Glassmeyer, S.T.; Pfaller, S. Microbial pathogens in source and treated waters from drinking water treatment plants in the united states and implications for human health. Sci. Total Environ. 2016, 562, 987-995. [CrossRef] [PubMed]

20. Richardson, S.D.; Kimura, S.Y. Water analysis: Emerging contaminants and current issues. Anal. Chem. 2016, 88, 546-582. [CrossRef] [PubMed]

21. Kong, L.; Kadokami, K.; Wang, S.; Duong, H.T.; Chau, H.T.C. Monitoring of 1300 organic micro-pollutants in surface waters from Tianjin, north China. Chemosphere 2015, 122, 125-130. [CrossRef] [PubMed]

22. Sebilo, M.; Mayer, B.; Nicolardot, B.; Pinay, G.; Mariotti, A. Long-term fate of nitrate fertilizer in agricultural soils. Proc. Natl. Acad. Sci. USA 2013, 110, 18185-18189. [CrossRef] [PubMed]

23. Schoumans, O.F.; Chardon, W.J.; Bechmann, M.E.; Gascuel-Odoux, C.; Hofman, G.; Kronvang, B.; Rubæk, G.H.; Ulén, B.; Dorioz, J.M. Mitigation options to reduce phosphorus losses from the agricultural sector and improve surface water quality: A review. Sci. Total Environ. 2014, 468, 1255-1266. [CrossRef] [PubMed]

24. Patrolecco, L.; Ademollo, N.; Grenni, P.; Tolomei, A.; Barra Caracciolo, A.; Capri, S. Simultaneous determination of human pharmaceuticals in water samples by solid phase extraction and HPLC with UV-fluorescence detection. Microchem. J. 2013, 107, 165-171. [CrossRef] 
25. Pruden, A. Balancing water sustainability and public health goals in the face of growing concerns about antibiotic resistance. Environ. Sci. Technol. 2014, 48, 5-14. [CrossRef] [PubMed]

26. Gopal, K.; Tripathy, S.S.; Bersillon, J.L.; Dubey, S.P. Chlorination byproducts, their toxicodynamics and removal from drinking water. J. Hazard. Mater. 2007, 140, 1-6. [CrossRef] [PubMed]

27. Richardson, S.D.; Postigo, C. Drinking water disinfection by-products. In Emerging Organic Contaminants and Human Health; Barceló, D., Ed.; Springer: Berlin/Heidelberg, Germany, 2012; pp. 93-137.

28. De Melo, B.A.G.; Motta, F.L.; Santana, M.H.A. Humic acids: Structural properties and multiple functionalities for novel technological developments. Mater. Sci. Eng. C 2016, 62, 967-974. [CrossRef] [PubMed]

29. Sharp, E.L.; Parsons, S.A.; Jefferson, B. Seasonal variations in natural organic matter and its impact on coagulation in water treatment. Sci. Total Environ. 2006, 363, 183-194. [CrossRef] [PubMed]

30. Schreiber, B.; Brinkmann, T.; Schmalz, V.; Worch, E. Adsorption of dissolved organic matter onto activated carbon-Te influence of temperature, absorption wavelength, and molecular size. Water Res. 2005, 39, 3449-3456. [CrossRef] [PubMed]

31. Holinger, E.P.; Ross, K.A.; Robertson, C.E.; Stevens, M.J.; Harris, J.K.; Pace, N.R. Molecular analysis of point-of-use municipal drinking water microbiology. Water Res. 2014, 49, 225-235. [CrossRef] [PubMed]

32. Wang, R.; Guan, S.; Sato, A.; Wang, X.; Wang, Z.; Yang, R.; Hsiao, B.S.; Chu, B. Nanofibrous microfiltration membranes capable of removing bacteria, viruses and heavy metal ions. J. Membr. Sci. 2013, 446, 376-382. [CrossRef]

33. Srinivasan, N.R.; Shankar, P.A.; Bandyopadhyaya, R. Plasma treated activated carbon impregnated with silver nanoparticles for improved antibacterial effect in water disinfection. Carbon 2013, 57, 1-10. [CrossRef]

34. National Health and Medical Research Concil. NRMMC (2011) Australian Drinking Water Guidelines Paper 6; Volume 2016 Update; Commonwealth of Australia: Canberra, Australia, 2011.

35. Rasheed, S.; Campos, L.C.; Kim, J.K.; Zhou, Q.; Hashmi, I. Optimization of total trihalomethanes' (TTHMS) and their precursors' removal by granulated activated carbon (GAC) and sand dual media by response surface methodology (RSM). Water Sci. Technol: Water Supply 2016, 16, 783-793. [CrossRef]

36. Fu, F.; Wang, Q. Removal of heavy metal ions from wastewaters: A review. J. Environ. Manag. 2011, 92, 407-418. [CrossRef] [PubMed]

37. Reza, R.; Singh, G. Heavy metal contamination and its indexing approach for river water. Int. J. Environ. Sci. Technol. 2010, 7, 785-792. [CrossRef]

38. Forgacs, E.; Cserháti, T.; Oros, G. Removal of synthetic dyes from wastewaters: A review. Environ. Int. 2004, 30, 953-971. [CrossRef] [PubMed]

39. Ahmed, M.B.; Zhou, J.L.; Ngo, H.H.; Guo, W. Adsorptive removal of antibiotics from water and wastewater: Progress and challenges. Sci. Total Environ. 2015, 532, 112-126. [CrossRef] [PubMed]

40. Rivera-Utrilla, J.; Sánchez-Polo, M.; Ferro-García, M.Á.; Prados-Joya, G.; Ocampo-Pérez, R. Pharmaceuticals as emerging contaminants and their removal from water. A review. Chemosphere 2013, 93, 1268-1287. [CrossRef] [PubMed]

41. Tepuš, B.; Simonič, M.; Petrinić, I. Comparison between nitrate and pesticide removal from ground water using adsorbents and NF and RO membranes. J. Hazard. Mater. 2009, 170, 1210-1217. [CrossRef] [PubMed]

42. Chen, S.-S.; Taylor, J.S.; Mulford, L.A.; Norris, C.D. Influences of molecular weight, molecular size, flux, and recovery for aromatic pesticide removal by nanofiltration membranes. Desalination 2004, 160, 103-111. [CrossRef]

43. Ando, N.; Matsui, Y.; Kurotobi, R.; Nakano, Y.; Matsushita, T.; Ohno, K. Comparison of natural organic matter adsorption capacities of super-powdered activated carbon and powdered activated carbon. Water Res. 2010, 44, 4127-4136. [CrossRef] [PubMed]

44. Yahya, M.A.; Al-Qodah, Z.; Ngah, C.W.Z. Agricultural bio-waste materials as potential sustainable precursors used for activated carbon production: A review. Renew. Sustain. Energy Rev. 2015, 46, 218-235.

45. Graese, S.L.; Snoeyink, V.L.; Lee, R.G. Granular activated carbon filter-adsorber systems. J. Am.Water Works Assoc. 1987, 79, 64-74.

46. Han, S.; Kim, S.; Lim, H.; Choi, W.; Park, H.; Yoon, J.; Hyeon, T. New nanoporous carbon materials with high adsorption capacity and rapid adsorption kinetics for removing humic acids. Microporous Mesoporous Mater. 2003, 58, 131-135. 
47. Pezoti, O.; Cazetta, A.L.; Bedin, K.C.; Souza, L.S.; Martins, A.C.; Silva, T.L.; Santos Júnior, O.O.; Visentainer, J.V.; Almeida, V.C. NaOH-activated carbon of high surface area produced from guava seeds as a high-efficiency adsorbent for amoxicillin removal: Kinetic, isotherm and thermodynamic studies. Chem. Eng. J. 2016, 288, 778-788.

48. Figueiredo, J.L. Functionalization of porous carbons for catalytic applications. J. Mater. Chem. A 2013, 1, 9351-9364.

49. Dąbrowski, A.; Podkościelny, P.; Hubicki, Z.; Barczak, M. Adsorption of phenolic compounds by activated carbon-A critical review. Chemosphere 2005, 58, 1049-1070. [PubMed]

50. Cheng, W.; Dastgheib, S.A.; Karanfil, T. Adsorption of dissolved natural organic matter by modified activated carbons. Water Res. 2005, 39, 2281-2290. [PubMed]

51. Ebie, K.; Li, F.; Azuma, Y.; Yuasa, A.; Hagishita, T. Pore distribution effect of activated carbon in adsorbing organic micropollutants from natural water. Water Res. 2001, 35, 167-179. [PubMed]

52. Pavoni, B.; Drusian, D.; Giacometti, A.; Zanette, M. Assessment of organic chlorinated compound removal from aqueous matrices by adsorption on activated carbon. Water Res. 2006, 40, 3571-3579. [PubMed]

53. Li, Y.; Du, Q.; Liu, T.; Peng, X.; Wang, J.; Sun, J.; Wang, Y.; Wu, S.; Wang, Z.; Xia, Y.; et al. Comparative study of methylene blue dye adsorption onto activated carbon, graphene oxide, and carbon nanotubes. Chem. Eng. Res. Des. 2013, 91, 361-368.

54. Li, L.; Quinlivan, P.A.; Knappe, D.R.U. Effects of activated carbon surface chemistry and pore structure on the adsorption of organic contaminants from aqueous solution. Carbon 2002, 40, 2085-2100. [CrossRef]

55. Zhang, Y.-J.; Ou, J.-L.; Duan, Z.-K.; Xing, Z.-J.; Wang, Y. Adsorption of Cr(VI) on bamboo bark-based activated carbon in the absence and presence of humic acid. Colloids Surf. A 2015, 481, 108-116. [CrossRef]

56. Nam, S.-W.; Choi, D.-J.; Kim, S.-K.; Her, N.; Zoh, K.-D. Adsorption characteristics of selected hydrophilic and hydrophobic micropollutants in water using activated carbon. J. Hazard. Mater. 2014, 270, 144-152. [CrossRef] [PubMed]

57. Newcombe, G.; Hayes, R.; Drikas, M. Granular activated carbon: Importance of surface properties in the adsorption of naturally occurring organics. Colloids Surf. A 1993, 78, 65-71. [CrossRef]

58. Prajapati, Y.N.; Bhaduri, B.; Joshi, H.C.; Srivastava, A.; Verma, N. Aqueous phase adsorption of different sized molecules on activated carbon fibers: Effect of textural properties. Chemosphere 2016, 155, 62-69. [CrossRef] [PubMed]

59. Pelekani, C.; Snoeyink, V.L. Competitive adsorption in natural water: Role of activated carbon pore size. Water Res. 1999, 33, 1209-1219. [CrossRef]

60. Mezohegyi, G.; van der Zee, F.P.; Font, J.; Fortuny, A.; Fabregat, A. Towards advanced aqueous dye removal processes: A short review on the versatile role of activated carbon. J. Environ. Manag. 2012, 102, 148-164. [CrossRef] [PubMed]

61. Collins, J.; Ngo, T.; Qu, D.; Foster, M. Spectroscopic investigations of sequential nitric acid treatments on granulated activated carbon: Effects of surface oxygen groups on $\pi$ density. Carbon 2013, 57, 174-183. [CrossRef]

62. Guedidi, H.; Reinert, L.; Lévêque, J.-M.; Soneda, Y.; Bellakhal, N.; Duclaux, L. The effects of the surface oxidation of activated carbon, the solution $\mathrm{pH}$ and the temperature on adsorption of ibuprofen. Carbon 2013, 54, 432-443. [CrossRef]

63. Yin, C.Y.; Aroua, M.K.; Daud, W.M.A.W. Review of modifications of activated carbon for enhancing contaminant uptakes from aqueous solutions. Sep. Purif. Technol. 2007, 52, 403-415. [CrossRef]

64. Zhi, Y.; Liu, J. Surface modification of activated carbon for enhanced adsorption of perfluoroalkyl acids from aqueous solutions. Chemosphere 2016, 144, 1224-1232. [CrossRef] [PubMed]

65. Reed, B.E.; Vaughan, R.; Jiang, L. As(III), $\mathrm{As}(\mathrm{V}), \mathrm{Hg}$, and $\mathrm{Pb}$ removal by Fe-oxide impregnated activated carbon. J. Environ. Eng. 2000, 126, 869-873. [CrossRef]

66. Jegadeesan, G.B.; Mondal, K.; Lalvani, S.B. Adsorption of Se (IV) and Se (VI) using copper-impregnated activated carbon and fly ash-extracted char carbon. Water Air Soil Pollut. 2015, 226, 1-12. [CrossRef]

67. Yürüm, A.; Kocabaş-Atakl1, Z.Ö.; Sezen, M.; Semiat, R.; Yürüm, Y. Fast deposition of porous iron oxide on activated carbon by microwave heating and arsenic (V) removal from water. Chem. Eng. J. 2014, 242, 321-332. [CrossRef] 
68. Watson, K.; Farré, M.J.; Knight, N. Comparing a silver-impregnated activated carbon with an unmodified activated carbon for disinfection by-product minimisation and precursor removal. Sci. Total Environ. 2016, 542, 672-684. [CrossRef] [PubMed]

69. Gonçalves, S.P.C.; Strauss, M.; Delite, F.S.; Clemente, Z.; Castro, V.L.; Martinez, D.S.T. Activated carbon from pyrolysed sugarcane bagasse: Silver nanoparticle modification and ecotoxicity assessment. Sci. Total Environ. 2016, 565, 833-840. [CrossRef] [PubMed]

70. Biswas, P.; Bandyopadhyaya, R. Water disinfection using silver nanoparticle impregnated activated carbon: Escherichia coli cell-killing in batch and continuous packed column operation over a long duration. Water Res. 2016, 100, 105-115. [CrossRef] [PubMed]

71. Alslaibi, T.M.; Abustan, I.; Ahmad, M.A.; Foul, A.A. A review: Production of activated carbon from agricultural byproducts via conventional and microwave heating. J. Chem. Technol. Biotechnol. 2013, 88, 1183-1190. [CrossRef]

72. Saucier, C.; Adebayo, M.A.; Lima, E.C.; Cataluña, R.; Thue, P.S.; Prola, L.D.T.; Puchana-Rosero, M.J.; Machado, F.M.; Pavan, F.A.; Dotto, G.L. Microwave-assisted activated carbon from cocoa shell as adsorbent for removal of sodium diclofenac and nimesulide from aqueous effluents. J. Hazard. Mater. 2015, 289, $18-27$. [CrossRef] [PubMed]

73. Ge, X.; Tian, F.; Wu, Z.; Yan, Y.; Cravotto, G.; Wu, Z. Adsorption of naphthalene from aqueous solution on coal-based activated carbon modified by microwave induction: Microwave power effects. Chem. Eng. Process. Process Intensif. 2015, 91, 67-77. [CrossRef]

74. Yao, S.; Zhang, J.; Shen, D.; Xiao, R.; Gu, S.; Zhao, M.; Liang, J. Removal of Pb(II) from water by the activated carbon modified by nitric acid under microwave heating. J. Colloid Interface Sci. 2016, 463, 118-127. [CrossRef] [PubMed]

75. Ihsanullah; Al-Khaldi, F.A.; Abu-Sharkh, B.; Abulkibash, A.M.; Qureshi, M.I.; Laoui, T.; Atieh, M.A. Effect of acid modification on adsorption of hexavalent chromium $(\mathrm{Cr}(\mathrm{VI}))$ from aqueous solution by activated carbon and carbon nanotubes. Desalin. Water Treat. 2016, 57, 7232-7244. [CrossRef]

76. Zhang, G.; Shi, L.; Zhang, Y.; Wei, D.; Yan, T.; Wei, Q.; Du, B. Aerobic granular sludge-derived activated carbon: Mineral acid modification and superior dye adsorption capacity. RSC Adv. 2015, 5, 25279-25286. [CrossRef]

77. Ihsanullah; Al-Khaldi, F.A.; Abusharkh, B.; Khaled, M.; Atieh, M.A.; Nasser, M.S.; laoui, T.; Saleh, T.A.; Agarwal, S.; Tyagi, I.; et al. Adsorptive removal of cadmium(II) ions from liquid phase using acid modified carbon-based adsorbents. J. Mol. Liq. 2015, 204, 255-263. [CrossRef]

78. Limousy, L.; Ghouma, I.; Ouederni, A.; Jeguirim, M. Amoxicillin removal from aqueous solution using activated carbon prepared by chemical activation of olive stone. Environ. Sci. Pollut. Res. 2016, 1-12. [CrossRef] [PubMed]

79. Mashhadi, S.; Javadian, H.; Ghasemi, M.; Saleh, T.A.; Gupta, V.K. Microwave-induced $\mathrm{H}_{2} \mathrm{SO}_{4}$ activation of activated carbon derived from rice agricultural wastes for sorption of methylene blue from aqueous solution. Desalin. Water Treat. 2016, 57, 21091-21104.

80. Erdogan, T.; Oguz Erdogan, F. Characterization of the adsorption of disperse yellow 211 on activated carbon from cherry stones following microwave-assisted phosphoric acid treatment. Anal. Lett. 2016, 49, 917-928. [CrossRef]

81. Thue, P.S.; dos Reis, G.S.; Lima, E.C.; Sieliechi, J.M.; Dotto, G.L.; Wamba, A.G.N.; Dias, S.L.P.; Pavan, F.A. Activated carbon obtained from sapelli wood sawdust by microwave heating for o-cresol adsorption. Res. Chem. Intermed. 2016, 1-25. [CrossRef]

82. Ge, X.; Wu, Z.; Wu, Z.; Yan, Y.; Cravotto, G.; Ye, B.-C. Microwave-assisted modification of activated carbon with ammonia for efficient pyrene adsorption. J. Ind. Eng. Chem. 2016, 39, 27-36. [CrossRef]

83. Martins, A.C.; Pezoti, O.; Cazetta, A.L.; Bedin, K.C.; Yamazaki, D.A.S.; Bandoch, G.F.G.; Asefa, T.; Visentainer, J.V.; Almeida, V.C. Removal of tetracycline by $\mathrm{NaOH}$-activated carbon produced from macadamia nut shells: Kinetic and equilibrium studies. Chem. Eng. J. 2015, 260, 291-299. [CrossRef]

84. Mestre, A.S.; Tyszko, E.; Andrade, M.A.; Galhetas, M.; Freire, C.; Carvalho, A.P. Sustainable activated carbons prepared from a sucrose-derived hydrochar: Remarkable adsorbents for pharmaceutical compounds. RSC Adv. 2015, 5, 19696-19707. [CrossRef] 
85. Niasar, H.S.; Li, H.; Kasanneni, T.V.R.; Ray, M.B.; Xu, C. Surface amination of activated carbon and petroleum coke for the removal of naphthenic acids and treatment of oil sands process-affected water (OSPW). Chem. Eng. J. 2016, 293, 189-199. [CrossRef]

86. Njoku, V.O.; Foo, K.Y.; Asif, M.; Hameed, B.H. Preparation of activated carbons from rambutan (Nephelium lappaceum) peel by microwave-induced $\mathrm{KOH}$ activation for acid yellow 17 dye adsorption. Chem. Eng. J. 2014, 250, 198-204. [CrossRef]

87. Saravanan, A.; Kumar, P.S.; Karthiga Devi, G.; Arumugam, T. Synthesis and characterization of metallic nanoparticles impregnated onto activated carbon using leaf extract of mukia maderasapatna: Evaluation of antimicrobial activities. Microbial Pathogenesis 2016, 97, 198-203. [CrossRef] [PubMed]

88. Abussaud, B.; Asmaly, H.A.; Ihsanullah; Saleh, T.A.; Gupta, V.K.; laoui, T.; Atieh, M.A. Sorption of phenol from waters on activated carbon impregnated with iron oxide, aluminum oxide and titanium oxide. J. Mol. Liq. 2016, 213, 351-359. [CrossRef]

89. Orha, C.; Pode, R.; Manea, F.; Lazau, C.; Bandas, C. Titanium dioxide-modified activated carbon for advanced drinking water treatment. Process Saf. Environ. Protect. 2016. [CrossRef]

90. Hu, X.; Zhang, H.; Sun, Z. Adsorption of low concentration ceftazidime from aqueous solutions using impregnated activated carbon promoted by iron, copper and aluminum. Appl. Surf. Sci. 2016, 392, 332-341. [CrossRef]

91. Mokhtari, P.; Ghaedi, M.; Dashtian, K.; Rahimi, M.R.; Purkait, M.K. Removal of methyl orange by copper sulfide nanoparticles loaded activated carbon: Kinetic and isotherm investigation. J. Mol. Liq. 2016, 219, 299-305. [CrossRef]

92. Trang, V.N.; Dan, N.P.; Phuong, L.D.; Thanh, B.X. Pilot study on the removal of TOC, THMS, and HAAS in drinking water using ozone/UV-BAC. Desalin. Water Treat. 2014, 52, 990-998. [CrossRef]

93. Lou, J.-C.; Yang, C.-Y.; Chang, C.-J.; Chen, W.-H.; Tseng, W.-B.; Han, J.-Y. Analysis and removal of assimilable organic carbon (AOC) from treated drinking water using a biological activated carbon filter system. J. Environ. Chem. Eng. 2014, 2, 1684-1690. [CrossRef]

94. LaPara, T.M.; Hope Wilkinson, K.; Strait, J.M.; Hozalski, R.M.; Sadowksy, M.J.; Hamilton, M.J. The bacterial communities of full-scale biologically active, granular activated carbon filters are stable and diverse and potentially contain novel ammonia-oxidizing microorganisms. Appl. Environ. Microbiol. 2015, 81, 6864-6872. [CrossRef] [PubMed]

95. Çeçen, F.; Aktaş, Ö. Activated Carbon for Water and Wastewater Treatment: Integration of Adsorption and Biological Treatment; Wiley-VCH Verlag GmbH \& Co. KGaA: Weinheim, Germany, 2011; p. 406.

96. Chu, W.; Gao, N.; Yin, D.; Deng, Y.; Templeton, M.R. Ozone-biological activated carbon integrated treatment for removal of precursors of halogenated nitrogenous disinfection by-products. Chemosphere 2012, 86, 1087-1091. [CrossRef] [PubMed]

97. Qin, W.; Li, W.-G.; Zhang, D.-Y.; Huang, X.-F.; Song, Y. Ammonium removal of drinking water at low temperature by activated carbon filter biologically enhanced with heterotrophic nitrifying bacteria. Environ. Sci. Pollut. Res. 2016, 23, 4650-4659. [CrossRef] [PubMed]

98. Lou, J.-C.; Chang, C.-J.; Chen, W.-H.; Tseng, W.-B.; Han, J.-Y. Removal of trihalomethanes and haloacetic acids from treated drinking water by biological activated carbon filter. Water Air Soil Pollut. 2014, 225, 1-9. [CrossRef]

99. Lou, J.-C.; Chan, H.-Y.; Han, J.-Y.; Yang, C.-Y. High removal of haloacetic acids from treated drinking water using bio-activated carbon method. Desalin. Water Treat. 2016, 1-12. [CrossRef]

100. Liu, C.; Sun, Y.; Wang, D.; Sun, Z.; Chen, M.; Zhou, Z.; Chen, W. Performance and mechanism of low-frequency ultrasound to regenerate the biological activated carbon. Ultrason. Sonochem. 2017, 34, 142-153. [CrossRef] [PubMed]

101. Rana, V.K.; Kissner, R.; Gaspard, S.; Levalois-Grützmacher, J. Cyclodextrin as a complexation agent in the removal of chlordecone from water. Chem. Eng. J. 2016, 293, 82-89. [CrossRef]

102. Luo, X.; Lei, X.; Cai, N.; Xie, X.; Xue, Y.; Yu, F. Removal of heavy metal ions from water by magnetic cellulose-based beads with embedded chemically modified magnetite nanoparticles and activated carbon. ACS Sustainable Chem. Eng. 2016, 4, 3960-3969. [CrossRef]

103. Jurado-Sánchez, B.; Sattayasamitsathit, S.; Gao, W.; Santos, L.; Fedorak, Y.; Singh, V.V.; Orozco, J.; Galarnyk, M.; Wang, J. Self-propelled activated carbon janus micromotors for efficient water purification. Small 2015, 11, 499-506. [CrossRef] [PubMed] 
104. Fornasiero, F.; Park, H.G.; Holt, J.K.; Stadermann, M.; Grigoropoulos, C.P.; Noy, A.; Bakajin, O. Ion exclusion by sub-2-nm carbon nanotube pores. Proc. Natl. Acad. Sci. USA 2008, 105, 17250-17255. [CrossRef] [PubMed]

105. Kalra, A.; Garde, S.; Hummer, G. Osmotic water transport through carbon nanotube membranes. PNAS 2003, 100, 10175-10180. [CrossRef] [PubMed]

106. Das, R.; Ali, M.E.; Hamid, S.B.A.; Ramakrishna, S.; Chowdhury, Z.Z. Carbon nanotube membranes for water purification: A bright future in water desalination. Desalination 2014, 336, 97-109. [CrossRef]

107. Thomas, M.; Corry, B. A computational assessment of the permeability and salt rejection of carbon nanotube membranes and their application to water desalination. Philos. Trans. A Math. Phys. Eng. Sci. 2015, 374, 20150020. [CrossRef] [PubMed]

108. Ren, X.; Chen, C.; Nagatsu, M.; Wang, X. Carbon nanotubes as adsorbents in environmental pollution management: A review. Chem. Eng. J. 2011, 170, 395-410. [CrossRef]

109. Das, R.; Abd Hamid, S.B.; Ali, M.E.; Ismail, A.F.; Annuar, M.S.M.; Ramakrishna, S. Multifunctional carbon nanotubes in water treatment: The present, past and future. Desalination 2014, 354, 160-179. [CrossRef]

110. Bui, N.; Meshot, E.R.; Kim, S.; Peña, J.; Gibson, P.W.; Wu, K.J.; Fornasiero, F. Ultrabreathable and protective membranes with sub-5 $\mathrm{nm}$ carbon nanotube pores. Adv. Mater. 2016, 28, 5871-5877. [CrossRef] [PubMed]

111. Sharma, V.K.; McDonald, T.J.; Kim, H.; Garg, V.K. Magnetic graphene-carbon nanotube iron nanocomposites as adsorbents and antibacterial agents for water purification. Adv. Colloid Interface Sci. 2015, 225, 229-240. [CrossRef] [PubMed]

112. Singh, G.; Rana, D.; Matsuura, T.; Ramakrishna, S.; Narbaitz, R.M.; Tabe, S. Removal of disinfection byproducts from water by carbonized electrospun nanofibrous membranes. Sep. Purif. Technol. 2010, 74, 202-212. [CrossRef]

113. Wang, Y.; Ma, J.; Zhu, J.; Ye, N.; Zhang, X.; Huang, H. Multi-walled carbon nanotubes with selected properties for dynamic filtration of pharmaceuticals and personal care products. Water Res. 2016, 92, 104-112. [CrossRef] [PubMed]

114. Lou, J.C.; Jung, M.J.; Yang, H.W.; Han, J.Y.; Huang, W.H. Removal of dissolved organic matter (DOM) from raw water by single-walled carbon nanotubes (SWCNTs). J. Environ. Sci. Health. Part A 2011, 46, 1357-1365. [CrossRef] [PubMed]

115. Ji, L.; Chen, W.; Duan, L.; Zhu, D. Mechanisms for strong adsorption of tetracycline to carbon nanotubes: A comparative study using activated carbon and graphite as adsorbents. Environ. Sci. Technol. 2009, 43, 2322-2327. [CrossRef] [PubMed]

116. Czech, B.; Oleszczuk, P. Sorption of diclofenac and naproxen onto MWCNT in model wastewater treated by $\mathrm{H}_{2} \mathrm{O}_{2}$ and/or UV. Chemosphere 2016, 149, 272-278. [CrossRef] [PubMed]

117. Jadhav, A.H.; Mai, X.T.; Ofori, F.A.; Kim, H. Preparation, characterization, and kinetic study of end opened carbon nanotubes incorporated polyacrylonitrile electrospun nanofibers for the adsorption of pyrene from aqueous solution. Chem. Eng. J. 2015, 259, 348-356. [CrossRef]

118. Gouda, A.A.; Al Ghannam, S.M. Impregnated multiwalled carbon nanotubes as efficient sorbent for the solid phase extraction of trace amounts of heavy metal ions in food and water samples. Food Chem. 2016, 202, 409-416. [CrossRef] [PubMed]

119. Zhang, X.; Huang, Q.; Liu, M.; Tian, J.; Zeng, G.; Li, Z.; Wang, K.; Zhang, Q.; Wan, Q.; Deng, F.; et al. Preparation of amine functionalized carbon nanotubes via a bioinspired strategy and their application in $\mathrm{Cu}^{2+}$ removal. Appl. Surf. Sci. 2015, 343, 19-27. [CrossRef]

120. Mubarak, N.M.; Sahu, J.N.; Abdullah, E.C.; Jayakumar, N.S. Rapid adsorption of toxic Pb(II) ions from aqueous solution using multiwall carbon nanotubes synthesized by microwave chemical vapor deposition technique. J. Environ. Sci. 2016, 45, 143-155. [CrossRef] [PubMed]

121. Gupta, V.K.; Moradi, O.; Tyagi, I.; Agarwal, S.; Sadegh, H.; Shahryari-Ghoshekandi, R.; Makhlouf, A.S.H.; Goodarzi, M.; Garshasbi, A. Study on the removal of heavy metal ions from industry waste by carbon nanotubes: Effect of the surface modification: A review. Critical Reviews in Environ. Sci. Technol. 2016, 46, 93-118. [CrossRef]

122. Ihsanullah; Abbas, A.; Al-Amer, A.M.; Laoui, T.; Al-Marri, M.J.; Nasser, M.S.; Khraisheh, M.; Atieh, M.A. Heavy metal removal from aqueous solution by advanced carbon nanotubes: Critical review of adsorption applications. Sep. Purif. Technol. 2016, 157, 141-161. [CrossRef] 
123. Liu, Y.; Cui, G.; Luo, C.; Zhang, L.; Guo, Y.; Yan, S. Synthesis, characterization and application of amino-functionalized multi-walled carbon nanotubes for effective fast removal of methyl orange from aqueous solution. RSC Adv. 2014, 4, 55162-55172. [CrossRef]

124. Naghizadeh, A.; Nasseri, S.; Rashidi, A.M.; Rezaei Kalantary, R.; Nabizadeh, R.; Mahvi, A.H. Adsorption kinetics and thermodynamics of hydrophobic natural organic matter (NOM) removal from aqueous solution by multi-wall carbon nanotubes. Water Sci. Technol. Water Supply 2013, 13, 273. [CrossRef]

125. Liu, F.-F.; Fan, J.-L.; Wang, S.-G.; Ma, G.-H. Adsorption of natural organic matter analogues by multi-walled carbon nanotubes: Comparison with powdered activated carbon. Chem. Eng. J. 2013, 219, 450-458. [CrossRef]

126. Datsyuk, V.; Kalyva, M.; Papagelis, K.; Parthenios, J.; Tasis, D.; Siokou, A.; Kallitsis, I.; Galiotis, C. Chemical oxidation of multiwalled carbon nanotubes. Carbon 2008, 46, 833-840. [CrossRef]

127. Ziegler, K.J.; Gu, Z.; Peng, H.; Flor, E.L.; Hauge, R.H.; Smalley, R.E. Controlled oxidative cutting of single-walled carbon nanotubes. J. Am. Chem. Soc. 2005, 127, 1541-1547. [CrossRef] [PubMed]

128. Marshall, M.W.; Popa-Nita, S.; Shapter, J.G. Measurement of functionalised carbon nanotube carboxylic acid groups using a simple chemical process. Carbon 2006, 44, 1137-1141. [CrossRef]

129. Krishna Kumar, A.S.; Jiang, S.-J.; Tseng, W.-L. Effective adsorption of chromium(VI)/Cr(III) from aqueous solution using ionic liquid functionalized multiwalled carbon nanotubes as a super sorbent. J. Mater. Chem. A 2015, 3, 7044-7057. [CrossRef]

130. Gong, J.-L.; Wang, B.; Zeng, G.-M.; Yang, C.-P.; Niu, C.-G.; Niu, Q.-Y.; Zhou, W.-J.; Liang, Y. Removal of cationic dyes from aqueous solution using magnetic multi-wall carbon nanotube nanocomposite as adsorbent. J. Hazard. Mater. 2009, 164, 1517-1522. [CrossRef] [PubMed]

131. Yu, F.; Ma, J.; Han, S. Adsorption of tetracycline from aqueous solutions onto multi-walled carbon nanotubes with different oxygen contents. Sci. Rep. 2014, 4, 5326. [CrossRef] [PubMed]

132. Ma, C.-Y.; Huang, S.-C.; Chou, P.-H.; Den, W.; Hou, C.-H. Application of a multiwalled carbon nanotube-chitosan composite as an electrode in the electrosorption process for water purification. Chemosphere 2016, 146, 113-120. [CrossRef] [PubMed]

133. Esfahani, M.R.; Tyler, J.L.; Stretz, H.A.; Wells, M.J.M. Effects of a dual nanofiller, nano- $\mathrm{TiO}_{2}$ and MWCNT, for polysulfone-based nanocomposite membranes for water purification. Desalination 2015, 372, 47-56. [CrossRef]

134. Yang, S.; Hu, J.; Chen, C.; Shao, D.; Wang, X. Mutual effects of $\mathrm{Pb}(\mathrm{II})$ and humic acid adsorption on multiwalled carbon nanotubes/polyacrylamide composites from aqueous solutions. Environ. Sci. Technol. 2011, 45, 3621-3627. [CrossRef] [PubMed]

135. Lee, J.; Ye, Y.; Ward, A.J.; Zhou, C.; Chen, V.; Minett, A.I.; Lee, S.; Liu, Z.; Chae, S.-R.; Shi, J. High flux and high selectivity carbon nanotube composite membranes for natural organic matter removal. Sep. Purif. Technol. 2016, 163, 109-119. [CrossRef]

136. Siddiqa, A.; Shahid, A.; Gill, R. Silica decorated cnts sponge for selective removal of toxic contaminants and oil spills from water. J. Environ. Chem. Eng. 2015, 3, 892-897. [CrossRef]

137. Chen, X.; Qiu, M.; Ding, H.; Fu, K.; Fan, Y. A reduced graphene oxide nanofiltration membrane intercalated by well-dispersed carbon nanotubes for drinking water purification. Nanoscale 2016, 8, 5696-5705. [CrossRef] [PubMed]

138. Oulton, R.; Haase, J.P.; Kaalberg, S.; Redmond, C.T.; Nalbandian, M.J.; Cwiertny, D.M. Hydroxyl radical formation during ozonation of multiwalled carbon nanotubes: Performance optimization and demonstration of a reactive CNT filter. Environ. Sci. Technol. 2015, 49, 3687-3697. [CrossRef] [PubMed]

139. Duman, O.; Tunç, S.; Polat, T.G.; Bozoğlan, B.K. Synthesis of magnetic oxidized multiwalled carbon nanotube- $\mathrm{k}$-carrageenan- $\mathrm{Fe}_{3} \mathrm{O}_{4}$ nanocomposite adsorbent and its application in cationic methylene blue dye adsorption. Carbohydr. Polym. 2016, 147, 79-88. [CrossRef] [PubMed]

140. Alsabagh, A.M.; Fathy, M.; Morsi, R.E. Preparation and characterization of chitosan/silver nanoparticle/copper nanoparticle/carbon nanotube multifunctional nano-composite for water treatment: Heavy metals removal; kinetics, isotherms and competitive studies. RSC Adv. 2015, 5, 55774-55783. [CrossRef]

141. Mattia, D.; Lee, K.P.; Calabrò, F. Water permeation in carbon nanotube membranes. Curr. Opin. Chem. Eng. 2014, 4, 32-37. [CrossRef]

142. Lee, K.-J.; Park, H.-D. The most densified vertically-aligned carbon nanotube membranes and their normalized water permeability and high pressure durability. J. Membr. Sci. 2016, 501, 144-151. [CrossRef] 
143. Lee, B.; Baek, Y.; Lee, M.; Jeong, D.H.; Lee, H.H.; Yoon, J.; Kim, Y.H. A carbon nanotube wall membrane for water treatment. Nat. Commun. 2015, 6. [CrossRef] [PubMed]

144. Trivedi, S.; Alameh, K. Effect of vertically aligned carbon nanotube density on the water flux and salt rejection in desalination membranes. SpringerPlus 2016, 5, 1158. [CrossRef] [PubMed]

145. Jafari, A.; Mahvi, A.H.; Nasseri, S.; Rashidi, A.; Nabizadeh, R.; Rezaee, R. Ultrafiltration of natural organic matter from water by vertically aligned carbon nanotube membrane. J. Environ. Health Sci. Eng. 2015, 13, 1-9. [CrossRef] [PubMed]

146. Jame Sadia, A.; Zhou, Z. Electrochemical carbon nanotube filters for water and wastewater treatment. Nanotechnol. Rev. 2016, 5, 41-50.

147. Vecitis, C.D.; Gao, G.; Liu, H. Electrochemical carbon nanotube filter for adsorption, desorption, and oxidation of aqueous dyes and anions. J. Phys. Chem. C 2011, 115, 3621-3629. [CrossRef]

148. Liu, Y.; Liu, H.; Zhou, Z.; Wang, T.; Ong, C.N.; Vecitis, C.D. Degradation of the common aqueous antibiotic tetracycline using a carbon nanotube electrochemical filter. Environ. Sci. Technol. 2015, 49, 7974-7980. [CrossRef] [PubMed]

149. Rahaman, M.S.; Vecitis, C.D.; Elimelech, M. Electrochemical carbon-nanotube filter performance toward virus removal and inactivation in the presence of natural organic matter. Environ. Sci. Technol. 2012, 46, 1556-1564. [CrossRef] [PubMed]

150. Brady-Estévez, A.S.; Kang, S.; Elimelech, M. A single-walled-carbon-nanotube filter for removal of viral and bacterial pathogens. Small 2008, 4, 481-484. [CrossRef] [PubMed]

151. Baek, Y.; Kim, C.; Seo, D.K.; Kim, T.; Lee, J.S.; Kim, Y.H.; Ahn, K.H.; Bae, S.S.; Lee, S.C.; Lim, J.; et al. High performance and antifouling vertically aligned carbon nanotube membrane for water purification. J. Membr. Sci. 2014, 460, 171-177. [CrossRef]

152. Dong, X.; Yang, L. Dual functional nisin-multi-walled carbon nanotubes coated filters for bacterial capture and inactivation. J. Biol. Eng. 2015, 9, 1-10. [CrossRef] [PubMed]

153. Wang, L.; Wang, X.; Zhou, J.-B.; Zhao, R.-S. Carbon nanotube sponges as a solid-phase extraction adsorbent for the enrichment and determination of polychlorinated biphenyls at trace levels in environmental water samples. Talanta 2016, 160, 79-85. [CrossRef] [PubMed]

154. Luan, J.; Hou, P.-X.; Liu, C.; Shi, C.; Li, G.-X.; Cheng, H.-M. Efficient adsorption of organic dyes on a flexible single-wall carbon nanotube film. J. Mater. Chem. A 2016, 4, 1191-1194. [CrossRef]

155. Dehghani, M.H.; Mohammadi, M.; Mohammadi, M.A.; Mahvi, A.H.; Yetilmezsoy, K.; Bhatnagar, A.; Heibati, B.; McKay, G. Equilibrium and kinetic studies of trihalomethanes adsorption onto multi-walled carbon nanotubes. Water Air Soil Pollut. 2016, 227, 1-17. [CrossRef]

156. Babaei, A.A.; Lima, E.C.; Takdastan, A.; Alavi, N.; Goudarzi, G.; Vosoughi, M.; Hassani, G.; Shirmardi, M. Removal of tetracycline antibiotic from contaminated water media by multi-walled carbon nanotubes: Operational variables, kinetics, and equilibrium studies. Water Sci. Technol. 2016, 74, 1202-1216. [CrossRef] [PubMed]

157. Patiño, Y.; Díaz, E.; Ordóñez, S.; Gallegos-Suarez, E.; Guerrero-Ruiz, A.; Rodríguez-Ramos, I. Adsorption of emerging pollutants on functionalized multiwall carbon nanotubes. Chemosphere 2015, 136, 174-180. [CrossRef] [PubMed]

158. Nie, C.; Peng, Z.; Yang, Y.; Cheng, C.; Ma, L.; Zhao, C. Kevlar based nanofibrous particles as robust, effective and recyclable absorbents for water purification. J. Hazard. Mater. 2016, 318, 255-265. [CrossRef] [PubMed]

159. Zouzelka, R.; Kusumawati, Y.; Remzova, M.; Rathousky, J.; Pauporté, T. Photocatalytic activity of porous multiwalled carbon nanotube- $\mathrm{TiO}_{2}$ composite layers for pollutant degradation. J. Hazard. Mater. 2016, 317, 52-59. [CrossRef] [PubMed]

160. Park, W.K.; Yoon, Y.; Kim, S.; Yoo, S.; Do, Y.; Kang, J.-W.; Yoon, D.H.; Yang, W.S. Feasible water flow filter with facilely functionalized $\mathrm{Fe}_{3} \mathrm{O}_{4}$-non-oxidative graphene/CNT composites for arsenic removal. J. Environ. Chem. Eng. 2016, 4, 3246-3252. [CrossRef]

161. Bakr, A.R.; Rahaman, M.S. Electrochemical efficacy of a carboxylated multiwalled carbon nanotube filter for the removal of ibuprofen from aqueous solutions under acidic conditions. Chemosphere 2016, 153, 508-520. [CrossRef] [PubMed]

162. Wang, J.; Lang, W.-Z.; Xu, H.-P.; Zhang, X.; Guo, Y.-J. Improved poly(vinyl butyral) hollow fiber membranes by embedding multi-walled carbon nanotube for the ultrafiltrations of bovine serum albumin and humic acid. Chem. Eng. J. 2015, 260, 90-98. [CrossRef] 
163. Peter, K.T.; Vargo, J.D.; Rupasinghe, T.P.; De Jesus, A.; Tivanski, A.V.; Sander, E.A.; Myung, N.V.; Cwiertny, D.M. Synthesis, optimization, and performance demonstration of electrospun carbon nanofiber-carbon nanotube composite sorbents for point-of-use water treatment. ACS Appl. Mater. Interfaces 2016, 8, 11431-11440. [CrossRef] [PubMed]

164. Geim, A.K.; Novoselov, K.S. The rise of graphene. Nat. Mater. 2007, 6, 183-191. [CrossRef] [PubMed]

165. Wang, S.; Ang, P.K.; Wang, Z.; Tang, A.L.L.; Thong, J.T.L.; Loh, K.P. High mobility, printable, and solution-processed graphene electronics. Nano Lett. 2010, 10, 92-98. [CrossRef] [PubMed]

166. Miao, X.; Tongay, S.; Petterson, M.K.; Berke, K.; Rinzler, A.G.; Appleton, B.R.; Hebard, A.F. High efficiency graphene solar cells by chemical doping. Nano Lett. 2012, 12, 2745-2750. [CrossRef] [PubMed]

167. Dreyer, D.R.; Park, S.; Bielawski, C.W.; Ruoff, R.S. The chemistry of graphene oxide. Chem. Soc. Rev. 2010, 39, 228-240. [CrossRef] [PubMed]

168. Cohen-Tanugi, D.; Grossman, J.C. Water desalination across nanoporous graphene. Nano Lett. 2012, 12, 3602-3608. [CrossRef] [PubMed]

169. Zeng, X.; McCarthy, D.T.; Deletic, A.; Zhang, X. Silver/reduced graphene oxide hydrogel as novel bactericidal filter for point-of-use water disinfection. Adv. Funct. Mater. 2015, 25, 4344-4351. [CrossRef]

170. Kyzas, G.Z.; Deliyanni, E.A.; Matis, K.A. Graphene oxide and its application as an adsorbent for wastewater treatment. J. Chem. Technol. Biotechnol. 2014, 89, 196-205. [CrossRef]

171. Gao, W.; Majumder, M.; Alemany, L.B.; Narayanan, T.N.; Ibarra, M.A.; Pradhan, B.K.; Ajayan, P.M. Engineered graphite oxide materials for application in water purification. ACS Appl. Mater. Interfaces 2011, 3, 1821-1826. [CrossRef] [PubMed]

172. Hu, M.; Mi, B. Enabling graphene oxide nanosheets as water separation membranes. Environ. Sci. Technol. 2013, 47, 3715-3723. [CrossRef] [PubMed]

173. Nair, R.R.; Wu, H.A.; Jayaram, P.N.; Grigorieva, I.V.; Geim, A.K. Unimpeded permeation of water through helium-leak-tight graphene-based membranes. Science 2012, 335, 442. [CrossRef] [PubMed]

174. Liang, B.; Zhang, P.; Wang, J.; Qu, J.; Wang, L.; Wang, X.; Guan, C.; Pan, K. Membranes with selective laminar nanochannels of modified reduced graphene oxide for water purification. Carbon 2016, 103, 94-100. [CrossRef]

175. Xia, S.; Ni, M.; Zhu, T.; Zhao, Y.; Li, N. Ultrathin graphene oxide nanosheet membranes with various d-spacing assembled using the pressure-assisted filtration method for removing natural organic matter. Desalination 2015, 371, 78-87. [CrossRef]

176. Carmalin Sophia, A.; Lima, E.C.; Allaudeen, N.; Rajan, S. Application of graphene based materials for adsorption of pharmaceutical traces from water and wastewater- a review. Desalin. Water Treat. 2016, 1-14. [CrossRef]

177. Hu, W.; Peng, C.; Luo, W.; Lv, M.; Li, X.; Li, D.; Huang, Q.; Fan, C. Graphene-based antibacterial paper. ACS Nano 2010, 4, 4317-4323. [CrossRef] [PubMed]

178. Yan, H.; Wu, H.; Li, K.; Wang, Y.; Tao, X.; Yang, H.; Li, A.; Cheng, R. Influence of the surface structure of graphene oxide on the adsorption of aromatic organic compounds from water. ACS Appl. Mater. Interfaces 2015, 7, 6690-6697. [CrossRef] [PubMed]

179. Sen Gupta, S.; Chakraborty, I.; Maliyekkal, S.M.; Adit Mark, T.; Pandey, D.K.; Das, S.K.; Pradeep, T. Simultaneous dehalogenation and removal of persistent halocarbon pesticides from water using graphene nanocomposites: A case study of lindane. ACS Sustain. Chem. Eng. 2015, 3, 1155-1163. [CrossRef]

180. Azamat, J.; Khataee, A.; Joo, S.W. Molecular dynamics simulation of trihalomethanes separation from water by functionalized nanoporous graphene under induced pressure. Chem. Eng. Sci. 2015, 127, 285-292. [CrossRef]

181. Abraham, J.; Vasu, K.S.; Williams, C.D.; Gopinadhan, K.; Su, Y.; Cherian, C.T.; Dix, J.; Prestat, E.; Haigh, S.J.; Grigorieva, I.V.; et al. Tunable sieving of ions using graphene oxide membranes. Nat. Nano 2017. [CrossRef] [PubMed]

182. Liu, S.; Zeng, T.H.; Hofmann, M.; Burcombe, E.; Wei, J.; Jiang, R.; Kong, J.; Chen, Y. Antibacterial activity of graphite, graphite oxide, graphene oxide, and reduced graphene oxide: Membrane and oxidative stress. ACS Nano 2011, 5, 6971-6980. [CrossRef] [PubMed]

183. Chen, J.; Peng, H.; Wang, X.; Shao, F.; Yuan, Z.; Han, H. Graphene oxide exhibits broad-spectrum antimicrobial activity against bacterial phytopathogens and fungal conidia by intertwining and membrane perturbation. Nanoscale 2014, 6, 1879-1889. [CrossRef] [PubMed] 
184. Sun, X.-F.; Qin, J.; Xia, P.-F.; Guo, B.-B.; Yang, C.-M.; Song, C.; Wang, S.-G. Graphene oxide-silver nanoparticle membrane for biofouling control and water purification. Chem. Eng. J. 2015, 281, 53-59. [CrossRef]

185. Rao, G.; Zhang, Q.; Zhao, H.; Chen, J.; Li, Y. Novel titanium dioxide/iron (III) oxide/graphene oxide photocatalytic membrane for enhanced humic acid removal from water. Chem. Eng. J. 2016, 302, 633-640. [CrossRef]

186. Bao, Q.; Zhang, D.; Qi, P. Synthesis and characterization of silver nanoparticle and graphene oxide nanosheet composites as a bactericidal agent for water disinfection. J. Colloid Interface Sci. 2011, 360, 463-470. [CrossRef] [PubMed]

187. Chen, Y.; Chen, L.; Bai, H.; Li, L. Graphene oxide-chitosan composite hydrogels as broad-spectrum adsorbents for water purification. J. Mater. Chem. A 2013, 1, 1992-2001. [CrossRef]

188. Wang, Y.; Li, L.; Luo, C.; Wang, X.; Duan, H. Removal of $\mathrm{Pb}^{2+}$ from water environment using a novel magnetic chitosan/graphene oxide imprinted $\mathrm{Pb}^{2+}$. Int. J. Biol. Macromol. 2016, 86, 505-511. [CrossRef] [PubMed]

189. Gao, H.; Sun, Y.; Zhou, J.; Xu, R.; Duan, H. Mussel-inspired synthesis of polydopamine-functionalized graphene hydrogel as reusable adsorbents for water purification. ACS Appl. Mater. Interfaces 2013, 5, 425-432. [CrossRef] [PubMed]

190. Ai, L.; Jiang, J. Removal of methylene blue from aqueous solution with self-assembled cylindrical graphene-carbon nanotube hybrid. Chem. Eng. J. 2012, 192, 156-163. [CrossRef]

191. Giménez-Pérez, A.; Bikkarolla, S.K.; Benson, J.; Bengoa, C.; Stüber, F.; Fortuny, A.; Fabregat, A.; Font, J.; Papakonstantinou, P. Synthesis of N-doped and non-doped partially oxidised graphene membranes supported over ceramic materials. J. Mater. Sci. 2016, 51, 8346-8360. [CrossRef]

192. Viraka Nellore, B.P.; Kanchanapally, R.; Pedraza, F.; Sinha, S.S.; Pramanik, A.; Hamme, A.T.; Arslan, Z.; Sardar, D.; Ray, P.C. Bio-conjugated CNT-bridged 3D porous graphene oxide membrane for highly efficient disinfection of pathogenic bacteria and removal of toxic metals from water. ACS Appl. Mater. Interfaces 2015, 7, 19210-19218. [CrossRef] [PubMed]

193. Kabiri, S.; Tran, D.N.H.; Azari, S.; Losic, D. Graphene-diatom silica aerogels for efficient removal of mercury ions from water. ACS Appl. Mater. Interfaces 2015, 7, 11815-11823. [CrossRef] [PubMed]

194. Vilela, D.; Parmar, J.; Zeng, Y.; Zhao, Y.; Sánchez, S. Graphene-based microbots for toxic heavy metal removal and recovery from water. Nano Lett. 2016, 16, 2860-2866. [CrossRef] [PubMed]

195. Yusuf, M.; Khan, M.A.; Abdullah, E.C.; Elfghi, M.; Hosomi, M.; Terada, A.; Riya, S.; Ahmad, A. Dodecyl sulfate chain anchored mesoporous graphene: Synthesis and application to sequester heavy metal ions from aqueous phase. Chem. Eng. J. 2016, 304, 431-439. [CrossRef]

196. Wan, S.; He, F.; Wu, J.; Wan, W.; Gu, Y.; Gao, B. Rapid and highly selective removal of lead from water using graphene oxide-hydrated manganese oxide nanocomposites. J. Hazard. Mater. 2016, 314, 32-40. [CrossRef] [PubMed]

197. Zhang, Y.; Zhang, S.; Gao, J.; Chung, T.-S. Layer-by-layer construction of graphene oxide (GO) framework composite membranes for highly efficient heavy metal removal. J. Membr. Sci. 2016, 515, 230-237. [CrossRef]

198. Tiwari, J.N.; Mahesh, K.; Le, N.H.; Kemp, K.C.; Timilsina, R.; Tiwari, R.N.; Kim, K.S. Reduced graphene oxide-based hydrogels for the efficient capture of dye pollutants from aqueous solutions. Carbon 2013, 56, 173-182. [CrossRef]

199. Cai, N.; Larese-Casanova, P. Application of positively-charged ethylenediamine-functionalized graphene for the sorption of anionic organic contaminants from water. J. Environ. Chem. Eng. 2016, 4, 2941-2951. [CrossRef]

(C) 2017 by the authors. Licensee MDPI, Basel, Switzerland. This article is an open access article distributed under the terms and conditions of the Creative Commons Attribution (CC BY) license (http:// creativecommons.org/licenses/by/4.0/). 